Portland State University

PDXScholar

1972

\title{
A functional interpretation of pottery from Batan Island, Philippines
}

Joanne M. Laetsch

Portland State University

Follow this and additional works at: https://pdxscholar.library.pdx.edu/open_access_etds

Part of the Archaeological Anthropology Commons, Art Practice Commons, and the Fine Arts Commons

Let us know how access to this document benefits you.

\section{Recommended Citation}

Laetsch, Joanne M., "A functional interpretation of pottery from Batan Island, Philippines" (1972).

Dissertations and Theses. Paper 959.

https://doi.org/10.15760/etd.959

This Thesis is brought to you for free and open access. It has been accepted for inclusion in Dissertations and Theses by an authorized administrator of PDXScholar. Please contact us if we can make this document more accessible: pdxscholar@pdx.edu. 
AN ABSTRACT OF THE THESIS OF Joanne M. Laetsch for the Master of Arts in Anthropology presented May 17, 1972.

Title: A Functional Interpretation of Pottery from Batan Island, PhIlippines.

APPROVED BY MEMBERS OF THE THESIS COMMTTEE:

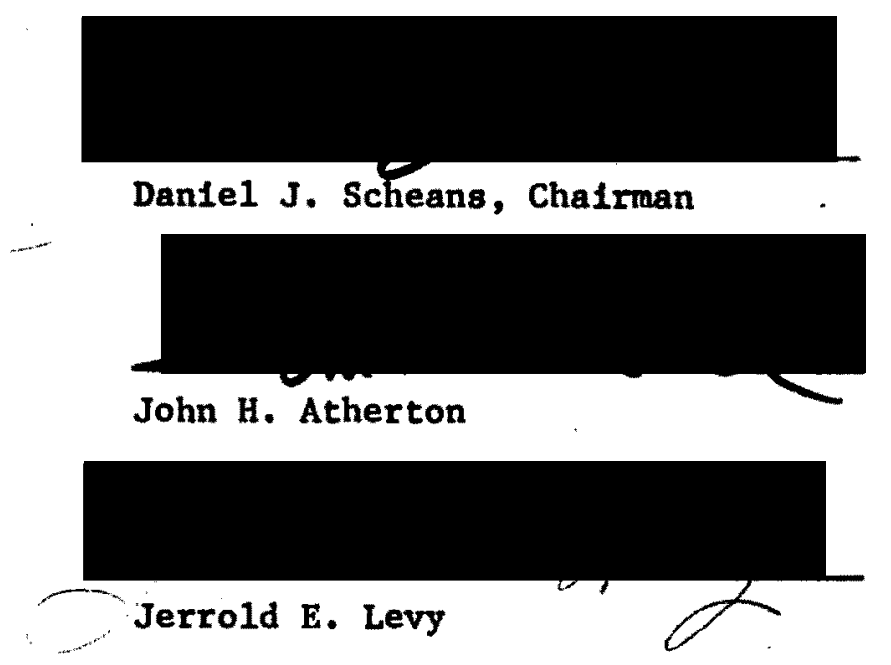

Th1s thesis is a report on a pottery analysis which was carrled out In the laboratory of the Department of Anthropology at Portland State UnIversity. The earthenware materlals Involved were collected from three surface sites on Batan Island, Ph1lippines, during the summer of 1969.

The interpretation of these potteries was based upon the direct-historical approach to archaeological research. The use of this method was proposed after a cursory examination of the earthenwares revealed certain general simflarities between the archaeological 
potteries and the ethnographically-known wares produced in the area at the present time. One of the sites was a known habitation, and the wares in this collection were analyzed to determine the characteristic ceramic attributes exhibited by the sherds. A comparison of these attributes with those noted in the collections from the other two sites revealed that the surface treatment and vessel form of all the wares were similar enough to Indicate only a minimal amount of functional variation between the sites.

Ethnographic data concerning the manufacture and use of contemporary earthenwares In the town of Uyogan, on Batan Island, revealed that these potteries are all strictly ut1litarian, and are used primarily in the preparation, handling, or storage of foodstuffs. By Inferring similar uses for similar 1tems in the past, the three collections of earthenwares appear to have been directly assoclated with habitation activities. Ethnographic and archaeological evidence from other areas in the PhIllppines Indicate that the materials from Batan are also comparable to earthenware 1tems produced elsewhere for "kitchen" purposes.

The three aurface collections of F111pino earthenwares have been analyzed with reference to function and use. It has been found that these materials are representative of the potteries used ethnographically in habitation activities in the area, and that the differences between the three collections may be attributable to diachronic rather than synchronic varlation. It is argued that once the characteristic ceramic attributes for any particular site are 
determined, their functional interdependence with habitation activities can be demonstrated. It 18 concluded that the direct-historical and ethnohistorical approaches can be utilized in the determination of site activities based upon the archaeological potterles found in them. 


\section{A FUNCTIONAI INTERPRETATION OF POTTERY \\ FROM BATAN ISLAND, PEIIIPPINES}

\section{by}

JOANNE M. LAETSCH

A thesis submitted in partial fulfillment of the requirements for the degree of

\section{MASTER OF ARTS \\ in ANTHROPOLOGY}

Portland State University

1972 
TO THE OFFICE OF GRADUATE STUDIES:

The members of the Committee approve the thesis of Joanne M. Laetsch presented May 17, 1972.

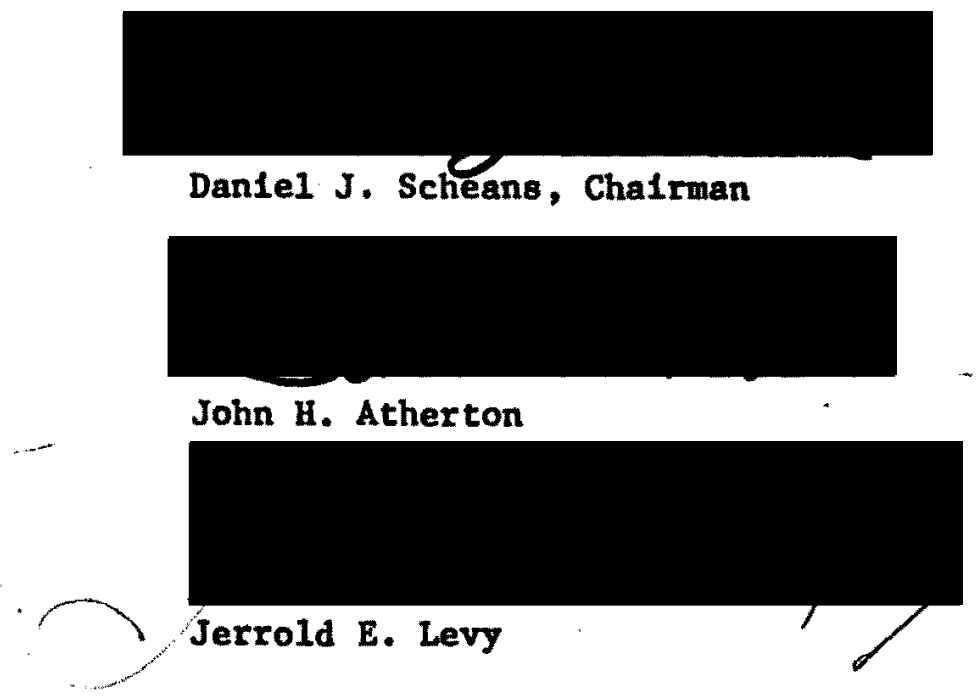

APPROVED:

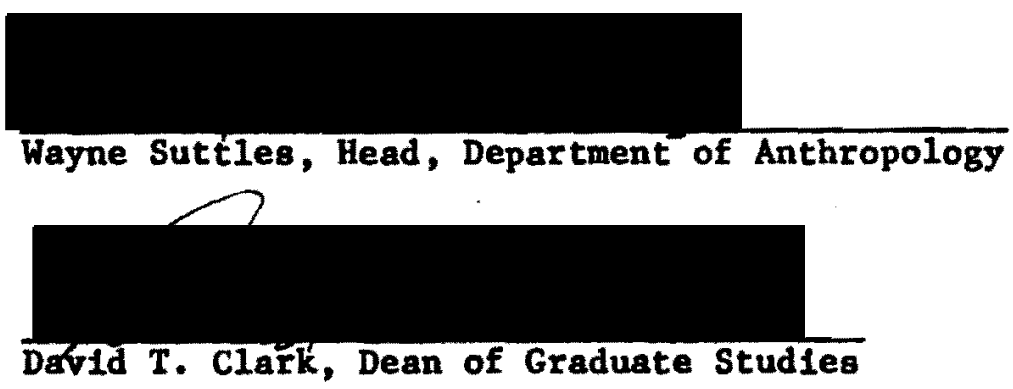

May 19,1972 
LIST OF TABLES ........................ . v LIST OF FIGURES ........................ . . vi CHAPTER

I INTRODUCTION ................... 1

Purpose ...................... 2

Assumptions ................ 3

Background ................. 5

II GEOGRAPHY AND SITE DESCRIPTIONS . . . . . . . . 8

The Area ............... 8

The Sites ............... 10

Method of Collection

Descriptions

III THE POTTERY STUDY . . . . . . . . . . . 14

Methodology ................ 14

Petrographic Analysis

Surface

Form

Analysis ................ 17

Site I

Site II

Site III 
III THE POTTERY STUDY (ContInued)

Discussion of forms ............. 31

Site I

SIte II

Site III

IV CONTEMPORARY UYOGAN EARTIEITWARES ......... 36

The Local Industry . . . . . . . . . 36

External Comparison ........... 38

The Kalinga

The Bontok and Bagobo

The Tinguian

The Ilokano

Central Philippines

Archaeological Comparisons . . . . . . . 42

The Kalanay Complex

The Kay Tomas Wares

V INTERPRETATION .................... 44

Surface Treatment............ 45

Vessel Form ............. 47

Kitchen Wares

Earthenware Disks

Miscellaneous

VI SUMMARY AND CONCLUSIONS ............ 50

REFERENCES CITED .................... 52

APPENDIX .................... 56 


\section{LIST OF TABLES}

TABLE

PAGE

I Size Range Comparisons of Archacological and Contemporary Wares ............. . 46 46 


\section{LIST OF FIGURES}

1 Map of Batanes Islands and Batan, Philipplnes . . . . 9

2 Rim Sherd Profiles from Site I . . . . . . . 23

3 Direct Rin Sherd Profiles from Site I . . . . . . 24

4 Base Sherd Profiles from Site I .......... 25

5 Everted and Straight Rim Sherd Profiles from

Site II................. 26

6 RIm and Bcdy Sherd Profiles from Site II . . . . . 27

7 Base and Tabular Handle Sherd Profiles from

Site II ................. 28

8 Rim Sherd Profiles from Site III . . . . . . . 29

9 Base Sherd Profiles from Site III . . . . . . 30

10 Formal Distribution of Body, Rim and Base Sherds

from Site I, by Percent and Number ..... 33

11 Formal Distribution of Body, Rim and Base Sherds

from Site II, by Percent and Number ..... 34

12 Formal Distribution of Body, Rim and Base Sherds

from Site III, by Percent and Number . . . . 35

13 Contemporary Uyogan Earthenwares . . . . . . . 37

14 Domestic and Inported Stoneware and

Porcelain Sherds .......... 60 


\section{CHAPTER I}

\section{INTRODUCTION}

Data concerning the manufacture and use of earthenwares in the PhIlippines have been so scant and of such varying quality that this type of Information can not be extensively utilized in archaeological Interpretation (Scheans, 1966: 214). This has been particularly true of the Batanes Islands, for which there are only two extant descriptions of pottery manufacture (Solhelm, 1952; Scheans, 1966), and only occasional mention of the uses to which these earthenwares were put. Similarly, the minimal anount of archaeological investigation which has been done throughout the region of the Batanes has dealt primarily with the excavation of jar-burial sites (Solheim, 1960). This dearth of information stimulated the research reported in this thesis: a functional analysis of three collections of potteries from surface sites on Batan Island.

The earthenware materials included in this study were collected durling the surmer of 1969 by Dr. Daniel J. Scheans of Portland State University. The three sites involved are all located on the southern end of the island of Batan, Batanes Province, in the northernmost region of the Philippines. At the same time, ethnographic information concerning the modern earthenware industry of the area was also gathered by Professor Scheans in the town of Uyogan, the southermmost municipality of the island. 


\section{PURPOSE}

The purpose of this study is to utilize a method designed to Incorporate ethnographic and archaeological data in order to yield significant information concerning cultural activities, as inferred from archaeological materials. The spectfic aims of this thesis are: (1) to present an argument for the use of analogy in inferring the activities of particular sites from the materials which they contain; and (2) to present a functional interpretation of archaeological potteries, based upon the use of ethnographic analogy.

This research consists of a two-part ceranic analysis. First, 1t was necessary to determine which ceramic attributes (formal or technological) noted in the archaeological potteries of a known habltation site are generally characteristic of living sites on Batan Island. These attributes were selected as indicators of the functional interdependence which exists between material remains and habitation activities. Second, the three collections were compared and contrasted, using the ceramic attributes as criteria, in order to determine possible synchronic (cultural or functional) variation between the three sites.

The materials represented have been analyzed with reference to their functional significance. It is necessary to distinguish here betiveen the two terms, function and use. During the course of this analysis, and throughout the text of this thesis, these terms have been employed as referents of two distinct but mutually 
interrelated aspects of cultural materials. This distinction was Inftially drawn by Ralph Linton (1936: 404), and his remains the most explictt statement:

The use of any cultural element is an expression of its relation to things external to the socio-cultural configuration; its function is an expression of 1 ts relation to things within that configuration. Thus, the axe has a use or uses with respect to the natural environment of the group, i.e., to chop wood. It has functions with respect both to the needs of the group and the operation of other elements within the culture configuration.

More recently, James Hill (1966: 10) ut1lized the terms in the same sense as Linton, describing the "functions" of speciflc cultural items as their association with ". . certain economic, sociological, or religious activities."

In the present study, the distinction between function and use consistently follows that proposed by Linton and used by Hill. The functions of the archaeological potteries are viewed in terms of their association with the many elements involved in habitation as a particular activity of a group of people. Their uses, however, may have been as vessels for cooking, serving, or other purposes.

\section{ASSUMPTIONS}

Mininally, this thesis is based upon three assumptions. The first is that any cultural items (in this case, earthenwares) function or functioned Interdependently with other material and "nonmaterial" aspects of culture. This has been supported by Binford (1968: 21) in his statenent that "it is virtually impossible to 
Imagine that any given cultural item functioned in a sociocultural system independently of the operation of 'non-material' variables." If this assumption is valid, then it should be possible to detect significant functional variation exhibited by the material remains.

The second assumption underlying this research is that the distribution of these items in archaeological sites is not random, but is rather evidence of patterned human behavior. Thus, it is possible to infer site activities from the material remains found in them. Watson, LeBlanc and Redman (1971: 116) have discussed this as a necessary framework for translating archaeological materials as evidence of the soclocultural systems "... In which they were produced, and in which they found their function." Varlants of this approach have been used by Hill (1966) in his analysis of Eroken $\mathrm{K}$ Pueblo in the Southwest, and by Longacre (1968) in making functional Inferences from the potteries of Carter Ranch.

In order to make such inferences about the potteries from Batan Island, the ethnographic evidence from Uyogan must be considered. Therefore, our third assumption is that there is a historical continuity between the archaeological materials and the ethnographic data from Eatan. By using the direct-historical approach, the information concerning present-day ceramic functions can be used to Infer similar functions for similar ttems in the past (Chang, 1967: 232). The application of the direct-inistorical and ethnohistorical approaches to the interpretction of archaeological data is not new. (Baerris, 1961; Watson, LeBlanc and Redman, 1971). Simflarly, the 
use of analogy with ethnographic materials has been widely discussed as a method for enhancing prehistoric research (Anderson, 1969; Ascher, 1961; Binford, 1967, 1968; Chang, 1967; Thompson, 1956). For Southeast Asia, W. G. Solhefm (1965) has discussed the possibility of studying archaeological potteries to determine their uses in various contexts, with the specific purpose of inferring their functions from the ethnographically known functions of simflar wares. The use of these methods, however, has seldom been applied to Investigations in the Philippines (Scheans, 1966: 214).

\section{BACKGROUND}

The archaeological data recovered from the Batanes Islands to date have been made up alnost exclusively of ceramic materials. Much of this Information has dealt with the earthenwares excavated in jar-burial sites. Beyer (1947: 210) discussed the Batanes jarburial evidence, and described it as perhaps the oldest jar-burial "type" In the Philippines. Solheim (1960: 130) refuted the Idea of a "jar-burial culture," emphasizing the considerable amount of variation which exists between the earthenware materials from different jar-burial locations within the Repub1ic. Despite this local specialization, there is considerable evidence in the Babuyan and Batanes Islands and in the Central Philippines of a widespread custom of jar-burial (Fox, 1959: 351; Terazas, 1968: 17).

In the Babuyan Islands, two kinds of fars were used for primary and secondary burials. The larger jars (primary burials) are 
of thick, locally manufactured earthenware or Imported Chinese stoneware with simflar jars or flat-bottomed bowls for lids, wh1le the smaller vessels (secondary burials) are of glazed stoneware with earthenware lids (Solheim, 1960: 126). These jars have been found buried in the ground or in shallow holes in solld coral, or above the surface in coral calrns, and are generally associated with beads of glass or stone, rings of metal, or earthenware, and occasionally with Chinese porcelain sherds (Solheim, 1960: 126, 127).

Earthenware and stoneware burlal jars have also been found in the Batanes (Solhein, 1960: 128). These had elther been buried in the ground without surface markers, or placed in the ground and covered by an earth mound, known locally as pada-paday (Beyer, 1947: 2.11). In the district of Uyogan on Batan Island, burial Jar sites have included Iron Age beads in association with Early Porcelain Age pieces, and a transition from Iron to Porcelain Age and historic material is suggested throughout the area (Beyer, 1947: 211). The only avallable information concerning the use of Batanes earthenwares prior to 1900 was recorded in 1778 by Don Juaquin Melgarejo (Manue1, 1953: 116). Melgarejo witnessed a jar-burial on the island of Batan. This indicates a relatively late survival of the custom, as discussed by Beyer (1947: 210) and Solheim (1960: 131).

Jar-burlal sites in the Batanes can be distinguished by the presence of the burial jars (with or without skeletal remains), their physical arrangenent, and the artifacts which are found in association with the jars (Solhefm, 1960: 115). Since no mounds, cairns 
or skeletal remains were found in assoclation with the potterles from the three sites under investigation, the possibility of their belng disturbed burlal sites like those discussed above has been discarded. The distinguishing attributes present in habitation sites in the Batanes, except for the actual remains of houses, have not yet been documented. For this reason, the present research is of value, since 1 t can contribute at least a small amount of Information on this sibject. 
CHAPTER II

GEOGRAPHY AND SITE DESCRIPTIONS

I. THE AREA

The Batanes Islands $\left(20^{\circ} 30^{\prime} \mathrm{N}, 121^{\circ} 50^{\prime} \mathrm{E}\right)$ comprise the northernmost limits of land in the Republic of the Philippines. They are composed of three large islands, Itbayat, Sabtang, and Batan, and numerous small islands and rocks (Figure 1). Together with the Babuyan Islands to the south, they form a single regional subdivision of the Philippines (Wernstedt and Spencer, 1967: 304). These two sma11 island groups lie 100 miles south of the Chinese islands of Taiwan and Botel Tobago. The Batanes are separated from Taiwan by the 16,000 feet deep Bashi Channel (Wernstedt and Spencer, 1967: 16).

The Batanes are isolated from the rest of the PhIlippines by their fragmented land area and rugged topography. Physlographically, they are part of a volcanic zone which extends southward into Luzon (Bemmelen, 1949: 34). Volcanic activity has played the most significant role in the formation of the islands, and in the creation of the soils of the area (Wernstedt and Spencer, 1967: 16).

The clinate of the Batanes-Babuyan region is generally humidtropical, and these Islands 1ie"... along one of the main typhoon tracks of the Western Pacific" (Wernstedt and Spencer, 1967: 310). Agriculture is the predominant form of livelihood, with 


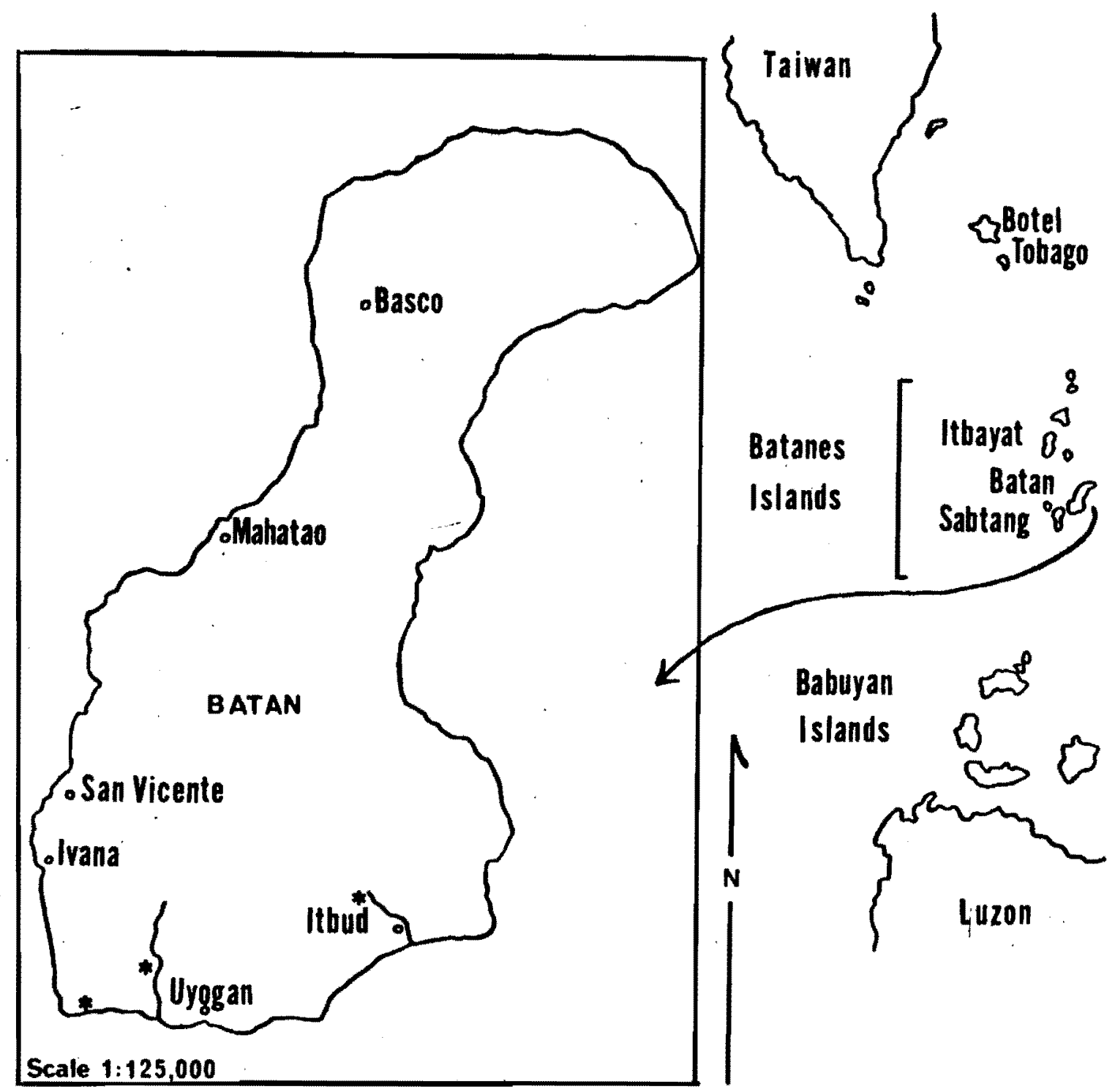

Flgure 1. Map of Batanes Islands and Batan, Phillppines. Stars (*) Indicate surface sites I, II, and III, from left to right. 
extensive cultivation of root crops. Rice and corn, the cereals favored in other parts of the Philippines, are not widely grown In the Batanes. This is partly because of the frequent typhoons. Camotes (sweet potatoes) are the primary staple food for the area. In addition, other vegetables and fruits grown include taro, yams, bananas, cltrus fruits, and coconuts (Wernstedt and Spencer, 1967: 311).

Batan Island is the largest and most populous of the Batanes group, with a total land area of 27 square miles (Wernstedt and Spencer, 1967: 16). Politically, it is divided into four municipalities: Sasco, the provincial capital, Mahatao, Ivana, and Uyogan. In 1960, the population of the Batanes Islands was 10,300 (Wernstedt and Spencer, 1967: 310). Nearly all of these inhabitants speak Ivatan, a language which has at best an indirect reiationship to the dialects spoken on Luzon (Keesing, 1962: 331).

\section{THE SITES}

Method of Collection

The three sites to be described are all within a five kilometer radius from the town of Uyogan. The total limits of each of the sites, as evidenced by the presence of surface sherds, were covered by two investigators, and an attempt was made to pick up all interesting, i.e., diagnostic, pieces, as well as a sample of the body sherds present. Thus, the collections cannot be classifled as random samples, but as selective ones designed to cover all the ceramic variation observable on the surfaces of the sites. 


\section{Descriptions}

S1te I: The Beach Site. This site is located approximately two kilometers west of Uyogan, on the south side of a large rock promontory at Kilometer Post 16 on the Basco-Uyogan road. This rock point extends into the sea, and is surrounded by the soils which make up the first terrace above the present-day beach. This terrace is a recognizable feature of the area, extending across the highway, and continuing eastward at least as far as Uyogan. The site itself is eroding out of this terrace because of wave action during stormy perlods, with the main cultural deposit some two meters above the normal high tide mark. The terrace soll is sandy silt, ranging in color from fron red to reddish brown. The cultural deposit contains some carbonized materials, most of which appear to be plant roots. Both the face of the site and the surface above it are covered with a heavy growth of pandanus, the roots of which can be seen to depths of about one meter. The site face covers an area of about $0.5 \times 5.0$ meters. Materlal collected: 101 earthenware sherds.

About 200 meters inland from the site is a house, the inhabitants of which are growing camotes and corn on the terrace. These informants indicated that there had been an old village site inland from the beach site. The investigators were not able to locate an apparent habitation site in this area.

Approximataly one kilometer east toward Uyogan, near Kilometer Post 17 , is the wreck of a Japanese ship from World War II. AccordIng to the school teacher in Uyogan, burlal fars were found between 
this wrecked ship and the beach site when their tops were uncovered by the erosion or displacement of the sand. One of these jars, without a rim, was in the Uyogan school, along with an earthenware plate with a foot-ring. Local Inhabitants were not sure of the association of the two items.

Site II: The Hill Site. Site II is located one kilometer east of Site I, toward Uyogan, and is directly inland from the Japanese ship on the beach. Located immediately north of the Kilometer Post is a ridge bounded by a large stream bed about ten meters to the east of $1 t$. The site is on the top and upper flanks of the ridge, covering not more than two hectares of land.

The surface soil of the site is brown sandy silt, resting on what appear to be cemented gravels. No indications of houses or habitation remains were found. The site consisted of sherds scattered over a field which had been plowed within two years of the time of investigation. It is wuch larger than the beach site, since the maxiraum extent of that site in the terrace wall at the beach is no moze than five meters.

Materfal collected: 177 earthenware sherds; 8 stoneware sherds.

Site III: The Mountain Site. This site is located on the top of a large hill that is approximately 500 feet high. It is about one-half kflometer Inland from the town of Itbud, some five kilometers east of Uyogan. Access to the site is through a river. velley and up narrow trails which in some places cut through 
abandoned stone terraces. The local people are famfllar with the site, since a number of them cross it frequently to reach their camote flelds located further inland.

The majority of the site materials were concentrated in an area of about one hectare in size, although scattered sherds are found all over the hill top. The soll on the site is quite dark, and much of it is gray-black. It has been badly disturbed by the rooting activities of pigs which forage throughout the area.

Though no standing house walls remained, scattered patches of stone walls can be seen all over the site. Along with them are pieces of the round stone ball mortar stones which are still used locally, and blocks of stone which have a polish on them like those in the town where people sit regularly, on the low walls outside the houses. This is clearly a habitation site, and would probably accommodate about ten small houses of the type seen in Uyogan and Itbud at the present time. Corroboration of this inference was given by the local people, who sald that it was a hab1tation site which had been occupled sometime in the recent past. Unfortunately, no one who had actually lived there could be located in Itbud.

Material coilected: 45 earthenware sherds, 23 imported and domestic stoneware sherds, 4 porcelain sherds, and 2 glass pleces (see Appendix). 
CHAPTER III

THE POTTERY STUDY

\section{METHODOLOGY}

The pottery study was carried out for the specific purpose of determining those ceramic attributes which are characteristic of the wares from each of the three sites. The earthenwares in each of the collections were analyzed separately from the stonewares and porcelain materials, since the latter are not of local manufacture. Since there were no restorable vessels in any of the collections, the analysis is based entirely upon sherd materials. This is not felt to be a serious handicap, however, because the majority of the materials exhibit certain close similarities to the ethnographically known potteries from Uyogan, and the forms of the wares have been inferred from these.

The earthenwares were subjected to a standard set of technological and formal analyses, in order to determine paste composition, method of manufacture, surface treatment, and vessel form. The methods employed in this phase of the study were based on those used by Anna 0 . Shepard (1956).

Initially, the sherds were sorted on the basis of exterior surface treatment; in this instance, the presence or absence of slipping and/or polishing. At the sane time, observations were 
made concerning surface color, interior treatment, and paste characteristics.

Petrographic Analysis

This portion of the pottery study was carried out by Mr. Brian L. Gannon of Portland State University. Thin sections of sherds from each of the three sites were made for comparative purposes, and one sherd was desegregated.

The pastes in the sherds in all three collections were found to be poorly compacted, and are quite gritty to the touch. There are no significant differences in paste composition or hardness between the materials from the three sites. The paste is essentially a crystalline volcanic ash, with an Andesitic-Basaltic composition.

An analysis of the grains in the pastes revealed that certain non-plastic Inclusions are present in varying amounts: Feldspar (Plagloclase), 54 per cent; Anphibole (Hornblende), 29 per cent; Magnetite, 12 per cent; Pyroxene, 3 per cent; other (rock fragments, oxides), 2 per cent. The sherd materials all appear to be from the same or similar sources. If the non-plastic inclusions were added as temper to the paste, a break in size could be expected between the claysize components and the temper. However, the crystalline components of the pastes range in size from coarse sand to the claysize fraction ( 1.0 to $0.0039 \mathrm{~mm}$.). It may be that these particles were not added intentionally by the potters, and that their presence in the clay was pre-determined by the materials used. In Uyogan, 
ethnographic information indicates that no temper is added by the potters at any time during the potting sequence. Macroscopic analysis of the pastes in the recent earthenwares has shown that similar inclusions are aiso present in the modern potteries.

The hardness of the earthenwares was determined by a simple scratch test using Moh's scale. The range of hardness into which the earthenwares fall, 2 to 4 , does not indicate any significant variation in paste, preparation or firing. Further, the hardness tests were rendered less accurate by the porous and heterogeneous character of the paste, and by the generally rough texture of the surfaces.

\section{Surface}

Nearly all of the sherds are s'ipped, wiped, and polished. Basically a red ware, the colors have been described with reference to a fublished color standard, the Munsell Soil Color Chart. This was done to establish the range of observed color variation, which runs from 10R 3/6, "dark red," to $7.5 \mathrm{YR} 6 / 3$, "reddIsh yellow," and a less common 1OYR 6/4, "light yellowish brown."

Form

Rin forms include everted or flaring rims, which extend outward from globular bodies, and direct rims in which the vessel side extends to the lip without any apparent variation in its contour. A few straight rims occur in the collections, and are vertical extensions from globular bodies. Two base forms are found: the ring-foot, made from a single coll attached to the base of the 
vessel prior to slipping; and the 'dimple' base, which is made by Indenting the base of a globular body, leaving an intertor bulge In cross-section.

The determination of vessel shape and size was naturally less definite than that which could be obtained from vessel reconstructions. The shapes and sizes of the vessels were extrapolated from the information gathered on rim form and diameter measurements, profiles, body contours, and base form and diameter. While the building process or processeg involved are still unknown, the earthenwares were subjected to at least the paddleand-anvil shaping technique, which is evidenced by anvil marks on the interior surfaces of the sherds.

\section{ANALYSIS}

\section{Site I}

of the 101 earthenware sherds collected at the beach site,

11 body sherds were too badly eroded for use in the analysis.

Paste: These materials are poorly compacted with numerous non-plastic inclusions, small crystals, granular particles and carbonized matter. The sherds are rough and gritty to the touch.

Hardness Range: 2 to 4 on Moh's scale.

Firing: Sherd interlors are zoned, showing a gray to black core in cross-section. This may be due to incomplete oxidation of the pastes in firing, although the presence of organic materials can also create this effect. 
Surface: All of the surfaces are thickly slipped and polished, showing wiping marks which appear as striations in the slip. The majority of the sherds are well-polished, leaving numerous indentations from the polishing tool. Fire clouds occur on 34 of the sherd surfaces, due to direct contact with the fuel during firing. 33 surfaces are extensively crazed.

Color: Slip colors range from dark red to red or reddish yellow. The majority are red and reddisin yellow.

Interiors: All interior surfaces appear to have been given the same treatment as the exteriors.

Form; Rin and lip: There are $45 \mathrm{rIm}$ sherds, representing three kinds of rims; everted, direct and straight.

Everted (Figure 2): 30 everted rims occur, all with rounded, round-pointed, or flattened lips. Six of the rims have a slight interior bulge at the 11p. All of the everted rims show marks which indicate polishing at the IIp and neck.

Size: Rim height range is 2.0 to $3.0 \mathrm{~cm}$; mean: $2.5 \mathrm{~cm}$; mouth djameter range is 11.0 to $27.0 \mathrm{~cm}$.; mean: $18.31 \pm$ $5.29 \mathrm{~cm}$.

Direct (Figure 3): The 14 direct rim sherds all have rounded, round-pointed or flattened lips. A few are incurving direct rims. One $\mathrm{rim}$ has a slight interior bulge at the 1ip. Direct rims occur with foot-rings on two shallow bowls, with mouth diameters of 14.4 and $22.5 \mathrm{~cm}$. One direct rin has a 'dimple' base, with a mouth diameter of $28.0 \mathrm{~cm}$.

Size: Mouth diameter range is 14.4 to $28.0 \mathrm{~cm}$; mean: $21.8 \pm 3.74 \mathrm{~cm}$.

Straight (Figure $2 ; j$ ): One vertical rim sherd has a rolled self-lip, flattened on the top.

Size: Rim height is $4.0 \mathrm{~cm}$; mouth diameter is $10.0 \mathrm{~cm}$.

Body sherds: Represented by 47 sherds, all with variable body wali thicknesses due to the uneven interior surfaces on all of the materials.

S1ze: Body wall thickness range: 0.5 to $1.2 \mathrm{~cm}$; body diameter unknown. 
Base: Nine sherds represent two base forms (Figure 4). 'Dimple': One sherd with a basal thickness of $1.8 \mathrm{~cm}$. Ring-foot: Eight sherds, all formed by attaching a single coll to the vessel base prior to slipping. Size: Foot helght range is 1.0 to $1.3 \mathrm{~cm}$.; mean: $1.1 \mathrm{~cm}$.; foot diameter range: 9.2 to $13.0 \mathrm{~cm}$; mean: $11.5 \pm 2.0 \mathrm{~cm}$.

Appendages: None.

Decoration: One everted rim has six vertical marks, 0.4 to $0.6 \mathrm{cr}$. apart, Impressed on the shoulder.

Rim-base relationships: Two direct rims occur with ring-foot bases; one direct rim occurs with a 'dimple' base.

\section{Site II}

There are 101 total sherds in this collection.

Paste: Same as the earthenwares from Site I.

Color: Pastes are generally reddish brown. Five sherds were fired to a light red or pink color with full oxidation of the paste.

Firing: Except for the pink wares, the sherds commonly show gray to black cores in cross-section.

Hardness range: 2 to 4 on Moh's scale.

Surface: 155 of the sherds are slipped and polished, 22 are polished but unslipped. These latter sherds include the pink wares, some brown sherds, and several blackened or smudged pieces. Slips are thick, usually well-polished, and the majority of surfaces show wiping marks as striations in the slip. Fire clouds are less common than in Site I.

Color: Slip colors range from reddish brown to red or dark red. Five sherds have a light brown or tan slip, which is extensively crazed. Red slips are the most common.

Interiors: These surfaces all received the same treatment as that given to the exterior surfaces.

Form; Rim and Lip: Three forms are represented by the rim sherds; everted, direct, and straight, with or without a rolled lip. 
Everted (Figure 5): 71 sherds, all with rounded or flattened lips. Polishing tool marks are generally deep on the rim exteriors.

Size: Rim height range is 1.6 to $3.6 \mathrm{~cm}$. ; mean: $2.4 \mathrm{~cm}$.; mouth dlameter range is 9.4 to $26.0 \mathrm{~cm}$; mean: $17.56+$ $4.49 \mathrm{~cm}$. These diameters appear to fall equally into three groups :

1) 9.4 to $13.4 \mathrm{~cm}$.

2) 15.0 to $13.0 \mathrm{~cm}$.

3) 21.0 to $26.0 \mathrm{~cm}$.

Direct (Figure $6 ;$ a-d): 25 sherds, all with rounded or flattened lips. One direct rim occurs on a sherd with a broken tabular handle between it and an angled shoulder (Figure 6; e).

Size: Mouth diameter range is 17.0 to $29.2 \mathrm{~cm}$; mean: 20.1 $\pm 3.12 \mathrm{~cm}$.

Stralght (Ffgure $5 ; \mathrm{h}-\mathrm{k}$ ): Six straight rims occur, two with flattened 1fps, and four with rolled self-11ps. One lip is folded to the Interior and undercut on the exterfor. These straight rims represent a minimum of five vessels.

Size: Rim height range is 2.0 to $3.0 \mathrm{~cm} . ;$ mean: $2.6 \mathrm{~cm}$. Mouth diameters range from 9.4 to $19.0 \mathrm{~cm}$.; mean: $11.44 \pm$ $3.79 \mathrm{~cm}$.

Body: There are 44 body sherds, exhibiting considerable variation in form. One sherd is half of a worked earthenware disk, slipped and polished. Disk diameter: $5.4 \mathrm{~cm}$. (Figure $6 ; g$ ).

Two sherds have perforated tabular handles, possibly representing one vessel (Figure $7 ; \mathrm{e}, \mathrm{f}$ ). The conical perforations were made from the top when the clay was fairly dry. Perforation widths are 0.6 and $0.3 \mathrm{~cm}$.; handle widths are 4.5 and $2.7 \mathrm{~cm}$.; handle heights are 1.5 and $1.3 \mathrm{~cm}$.; handle thicknesses are 1.3 and $0.9 \mathrm{~cm}$.

One angled shoulder sherd occurs, made of pink-fired paste (Figure 6, f).

There are five layered sherds which represent at least two vessels. These layers may be due elther to poor bonding of the materials in firing, or to the addition of clay to the already formed body at some time during the building process. The layer thicknesses range from 1.5 to $3.3 \mathrm{~cm}$.

Body wall thicknesses range from 0.5 to $3.3 \mathrm{~cm}$; mean: 1.0 $\pm 0.3 \mathrm{~cm}$. 
Base: 31 base sherds represent two forms, the 'dimple' and the ring-foot.

'Dimple' (Figure 7; c, d): Three sherds with a basal

thickness of 0.9 to $1.1 \mathrm{~cm}$.

Ring-foot (Figure 7; a, b): There are 28 ring-foot bases.

Two sherds are from a single vessel, and have a single conical perforation through the coll of each of the footrings. The perforations were made in fairly dry clay from the outside. The foot height range is 0.6 to $1.4 \mathrm{~cm}$.;

mean: $1.0 \mathrm{~cm}$., and the foot diameter range is 6.0 to $12.0 \mathrm{~cm}$. ; mean: $9.2 \mathrm{~cm}$.

Appendages: Two tabular handles with perforations, one broken tabular handle on a vessel with a direct rin and an angled shoulder.

Decoration: None.

\section{Site III}

Paste: 15 of the 45 total sherds are of a well-compacted paste with a sandstone-1ike texture which is smoother to the touch than the others. The remainder of the sherds are of less well-compactod pastes and contain numerous nonplastic inclusions.

Hardness Range: 2 to 4 on Moh's scale.

Firing: Sherds of the more porous pastes show gray to black cores in cross-section. The finer pastes are well-oxidized.

Surface: 30 of the sherds are slipped and polished, and 13 are polfshed but unslipped. $\Lambda 11$ of the sherds show definite polishing marks, and all slipped surfaces have well-defined wiping marks. Fire clouds occur on only three surfaces. Crazing is common on the exterior surfaces.

Interfors: All interiors appear to have been given the same treatment as the exterior surfaces.

Form; Rim and 11p: $17 \mathrm{rIm}$ sherds were found at site III. The two forms are everted and direct rims.

Everted (Figure $8 ; \mathrm{a}-\mathrm{h}$ ): There are 15 everted rims, all with rounded or flattened lips. The rin height range is 1.2 to $3.0 \mathrm{~cm}$.; mean: $2.2 \mathrm{~cm}$. The mouth diameter range 189.0 to $24.6 \mathrm{~cm}$.; mean: $17.4 \pm 5.5 \mathrm{~cm}$. 
Direct (Figure $8 ; 1, j$ ): There are four inturned direct rims, all with round, rouni-pointed, or flattened 11ps. One direct rim occurs with a foot-ring (Figure 9; c, d), and one with a 'dimple' base. The mouth dlameter range 1813.6 to $22.8 \mathrm{~cm}$.

Body: There are 14 body wall sherds, with a thickness range of 0.4 to $1.3 \mathrm{~cm}$.; mean: $0.8 \mathrm{~cm}$.

Base: Three base forms are represented by 13 sherds.

Ring-foot (Figure 9; a-d): The nine foot-rings are elther rounded or flattened. The foot height range is 0.9 to $1.2 \mathrm{~cm}$; mean: $1.1 \mathrm{~cm}$. The foot diameters range from 5.0 to $11.0 \mathrm{~cm}$.; mean: $8.1 \mathrm{~cm}$.

'Dimple' (Figure 9; e): Three base sherds with a thickness of 1.0 to $1.2 \mathrm{~cm}$.

Flat, circular: One sherd resembles a flattened 'dimple' base. Two layers at the base are shown in cross-section, which appear to have been caused by poor bonding of the paste in firing, due to the $2.3 \mathrm{~cm}$. thickness of the ware.

Appendages: None.

Decoration: None. 


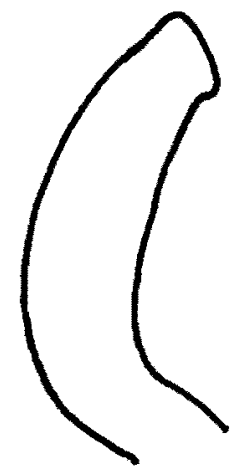

a.

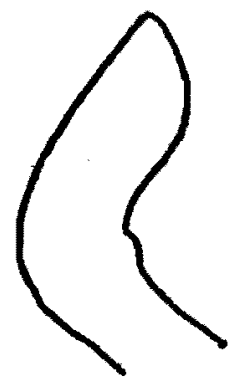

e.

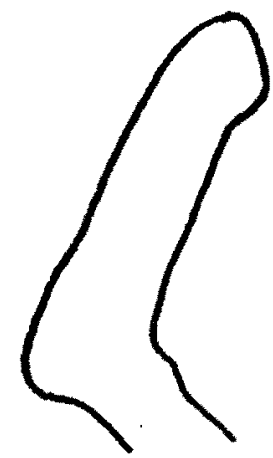

h.

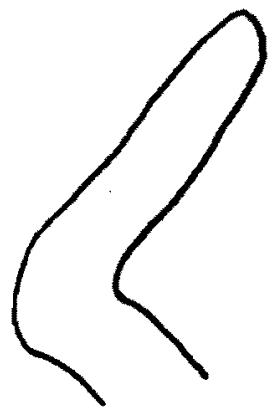

b.

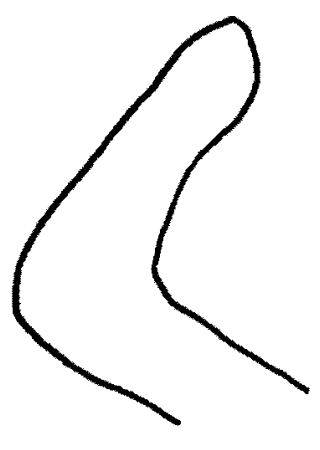

f.

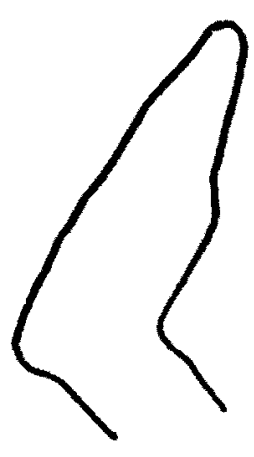

1.
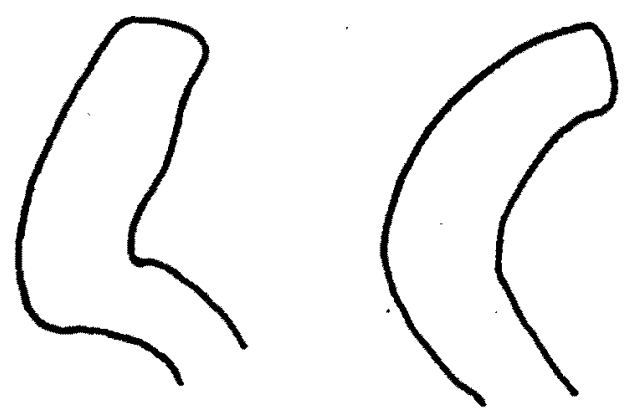

c.

d.
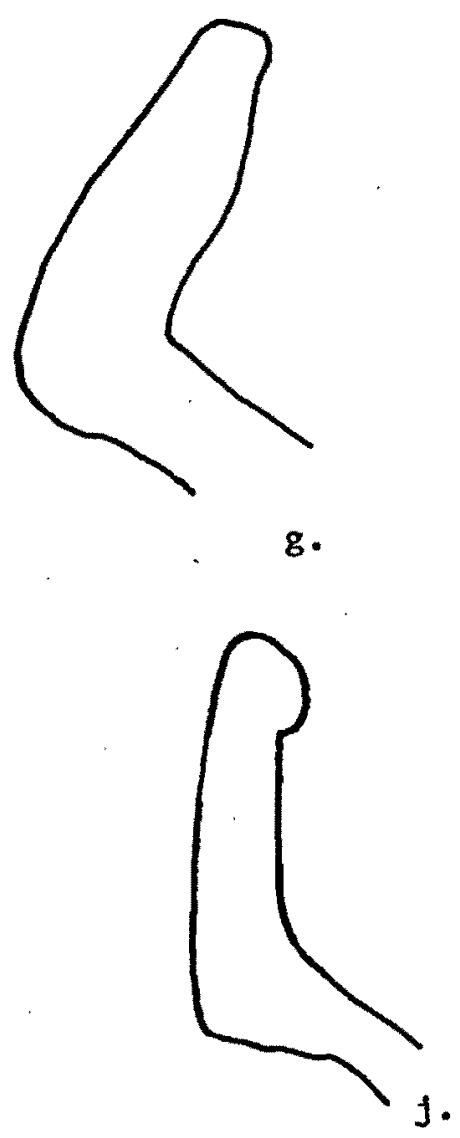

$\longrightarrow 1 \mathrm{CM}$

Figure 2. Riru sherd profiles from Site I. Everted rims, a - 1; straight rim, $j$. Interiors drawn to the left. 


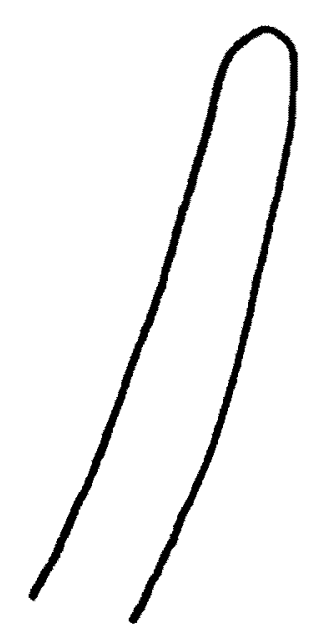

a.

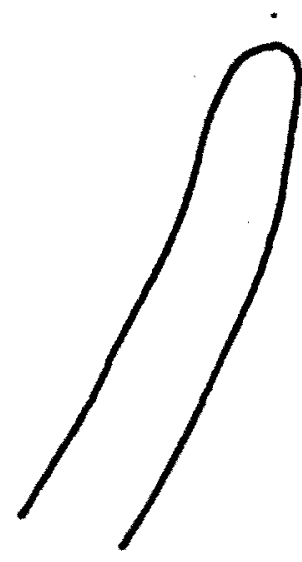

b.

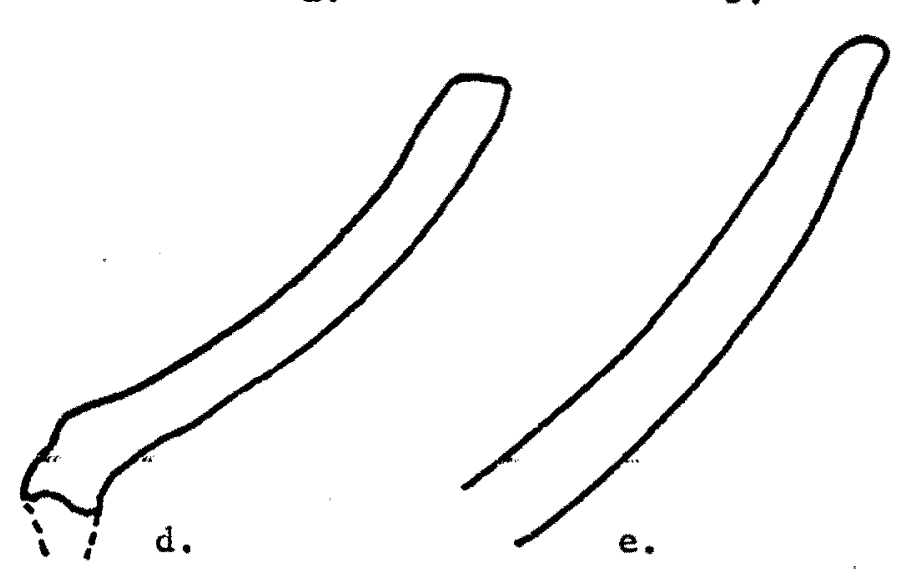

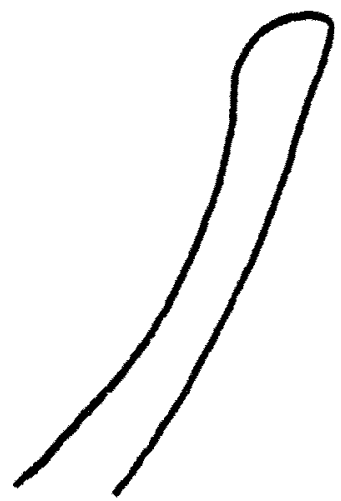

g.

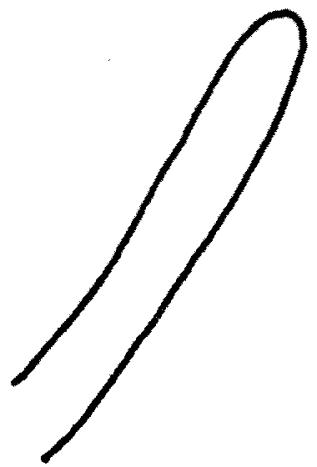

h.
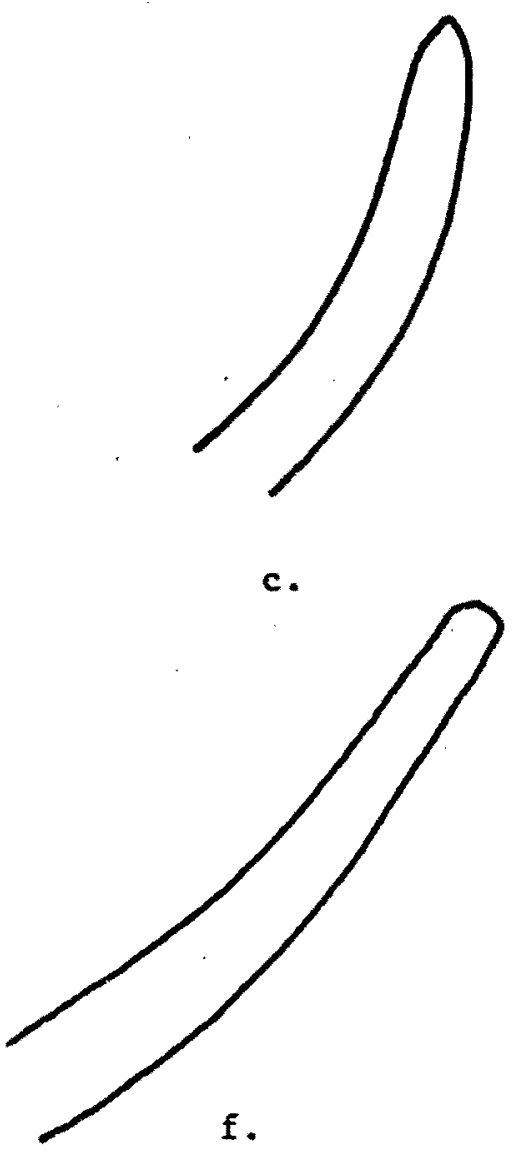

c. 

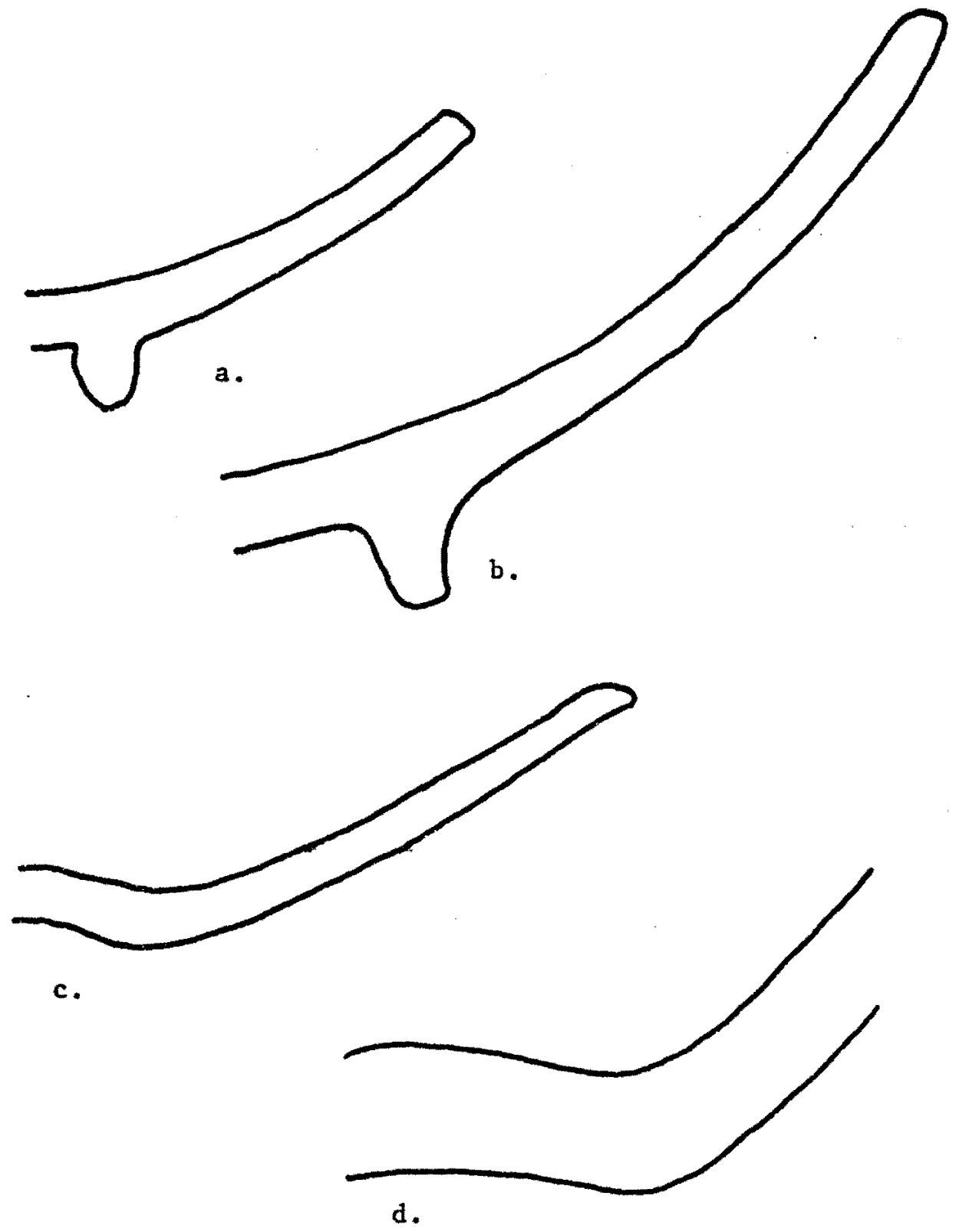

$\longrightarrow 1 \mathrm{CM}$

Figure 4. Base sherd profiles from Site I. Ring-foot bases, $a$ and $b$; 'dimple' bases, $c$ and $d$. Interiors drawn to the left. 

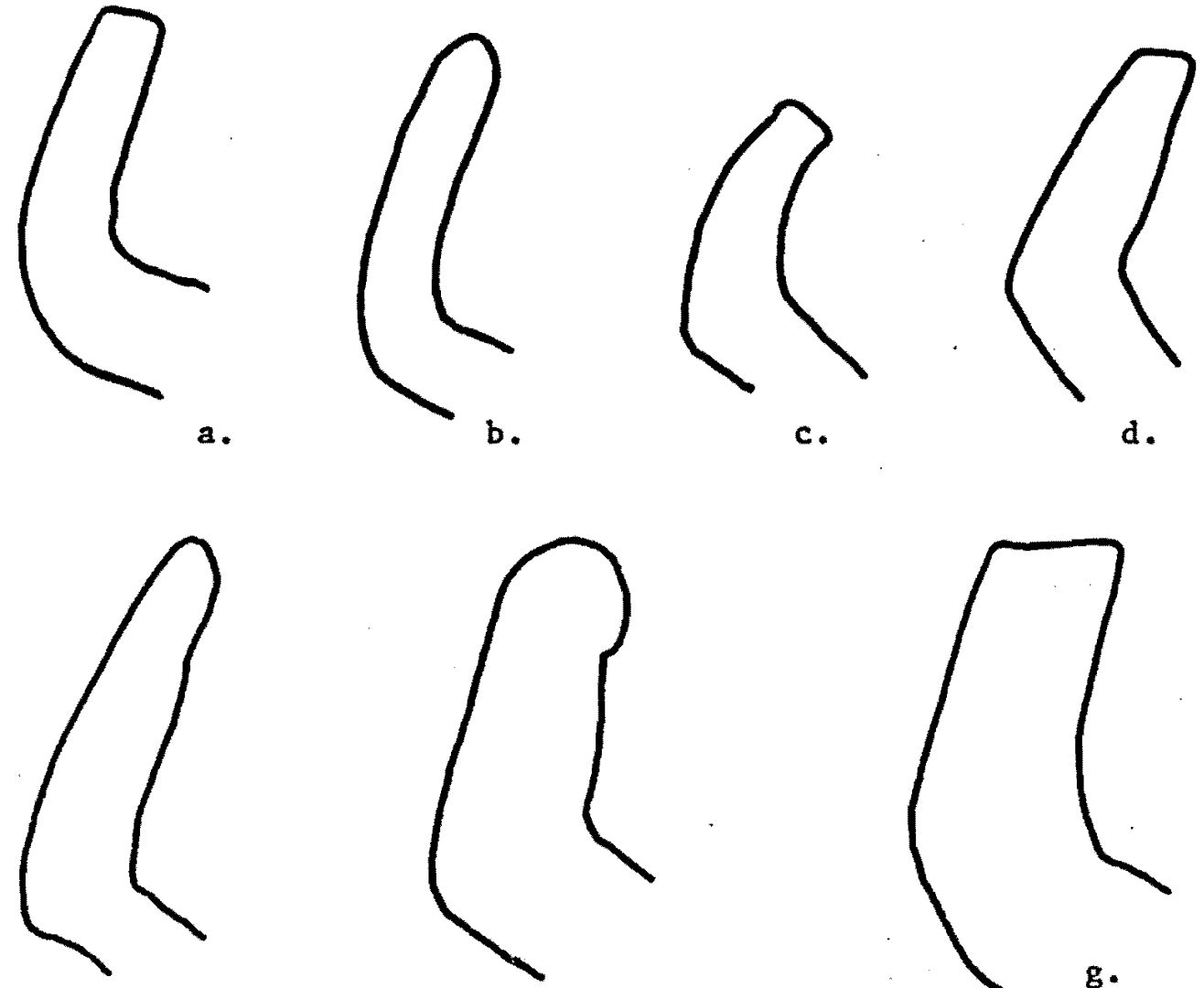

e.
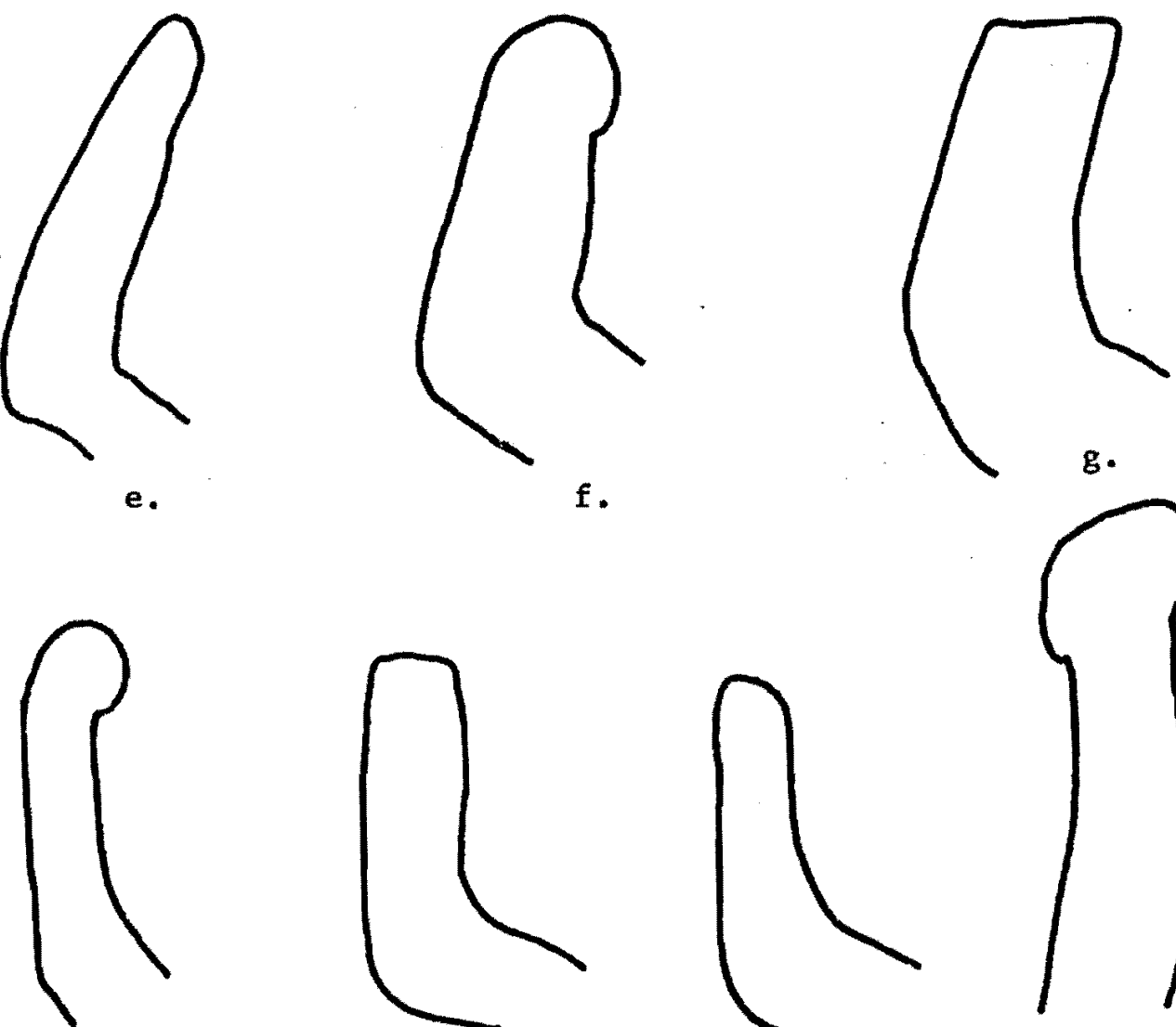

h.
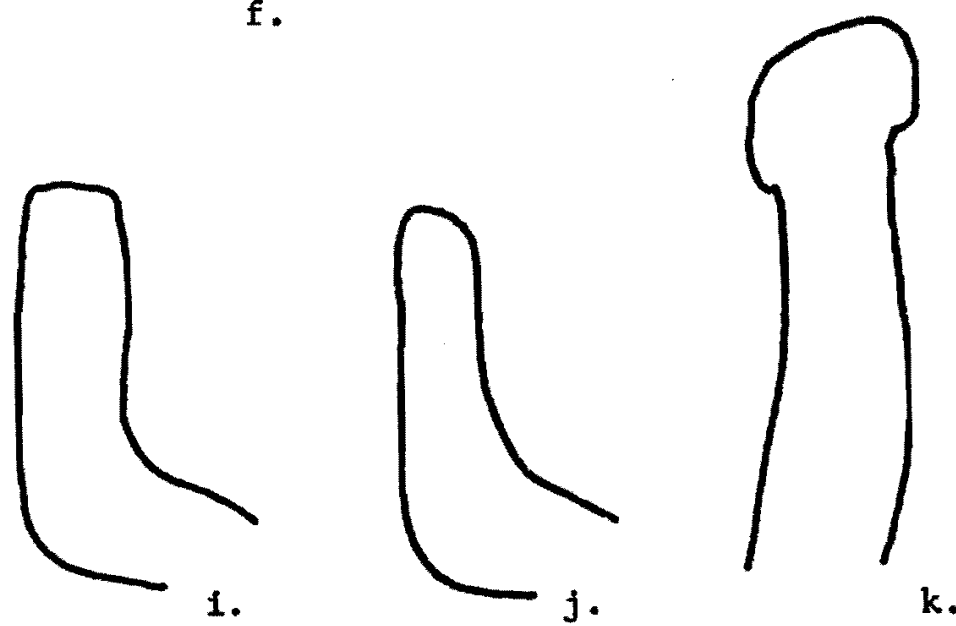

$1 \mathrm{CM}$

Flgure 5. Everted and stralght rim sherd profiles from Site II. Everted rims, a - g; straight rims, $h-k$. Interlors drawn to the left. 
27

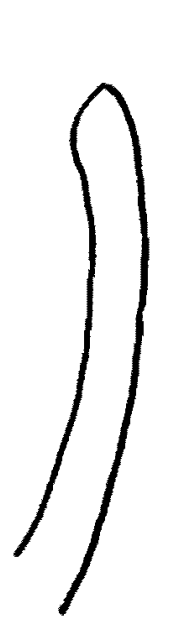

a.

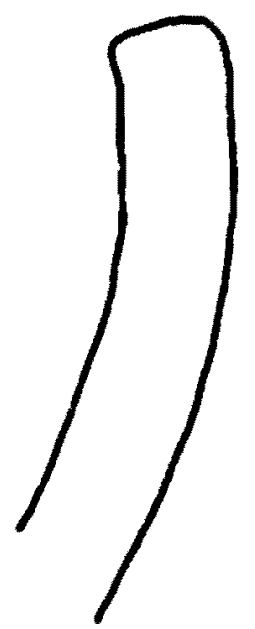

b.

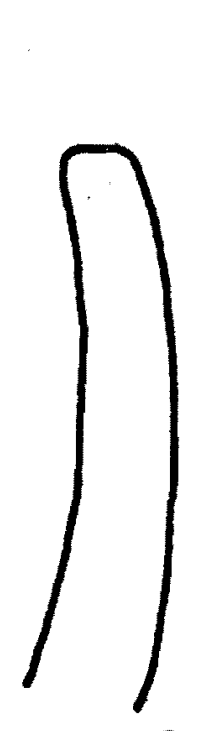

c.

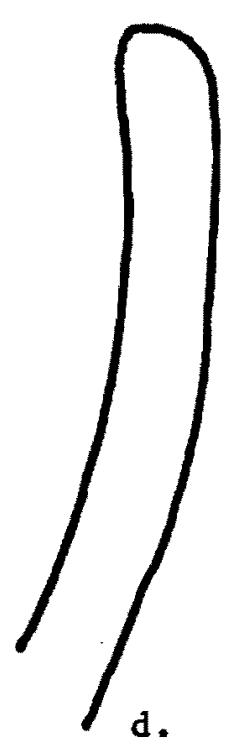

d.
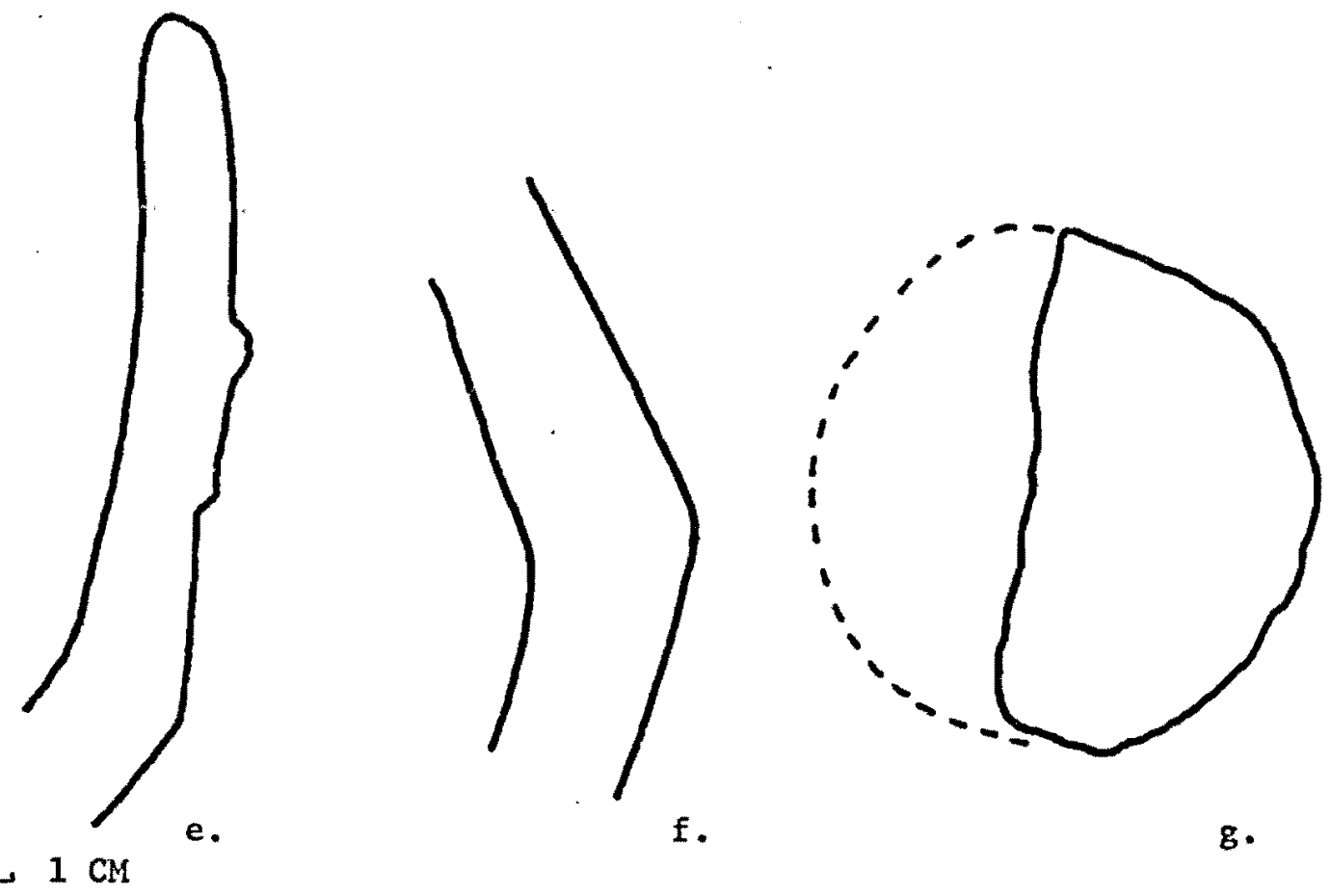

f.

g.

FIgure 6. Rim and body sherd profiles from Site II. Direct rims, a - d; direct rim with broken 'tab' handle and angled shoulder, e; angled shoulder, f; disk, g. Interiors drawn to the left. 

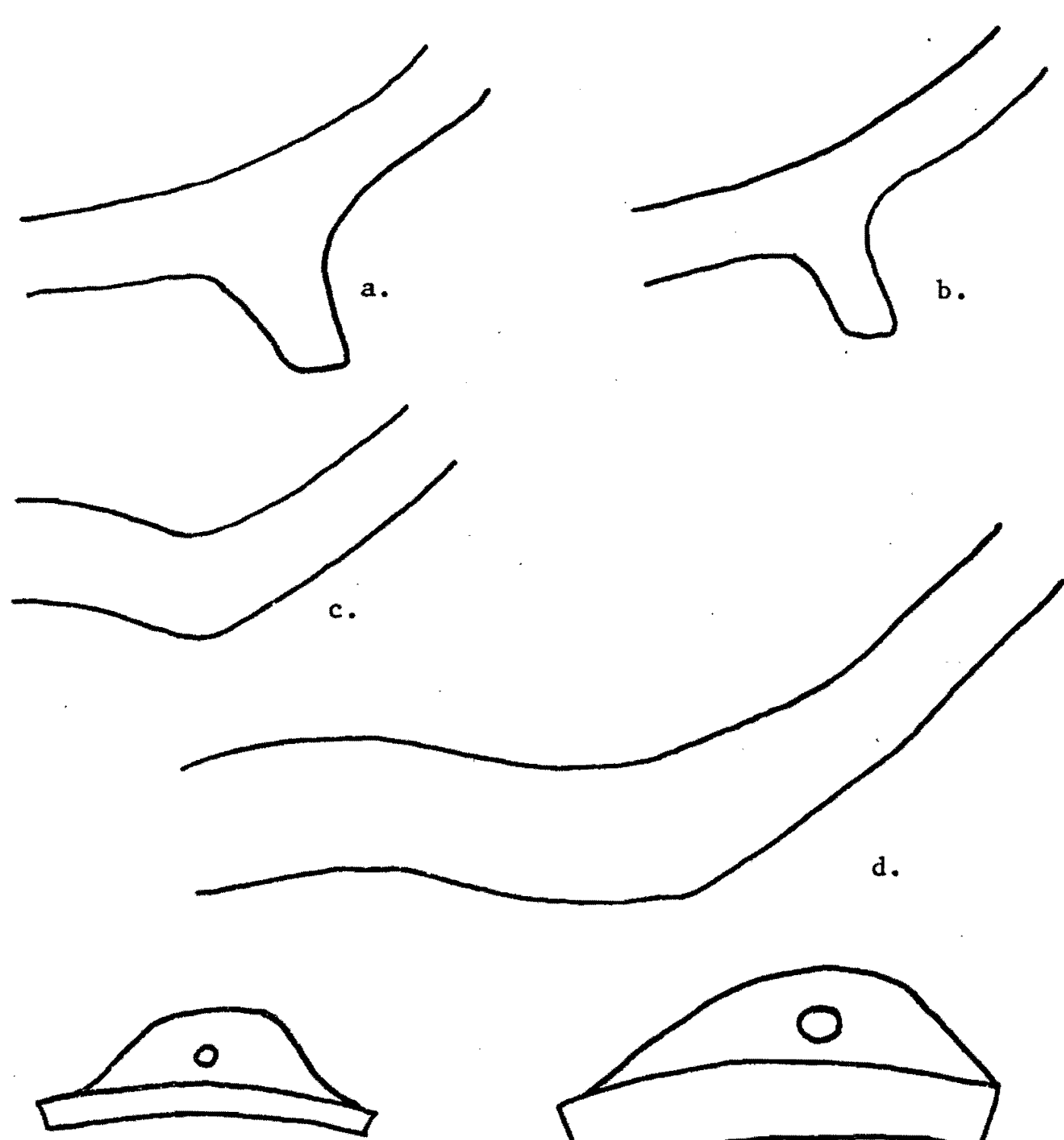

e.

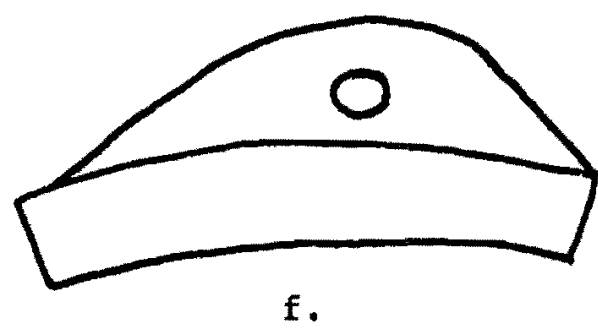

$1 \mathrm{CM}$

Figure 7. Base and tabular handle sherd profiles from Site II. Ring-foot bases, $a$ and $b$; 'dimple' bases, $c$ and $d$; tabular handles, top view, $e$ and $f$. Interiors drawn to the left on a - d. 


$$
\begin{aligned}
& R R R R \\
& R \ll R \\
& R S)
\end{aligned}
$$



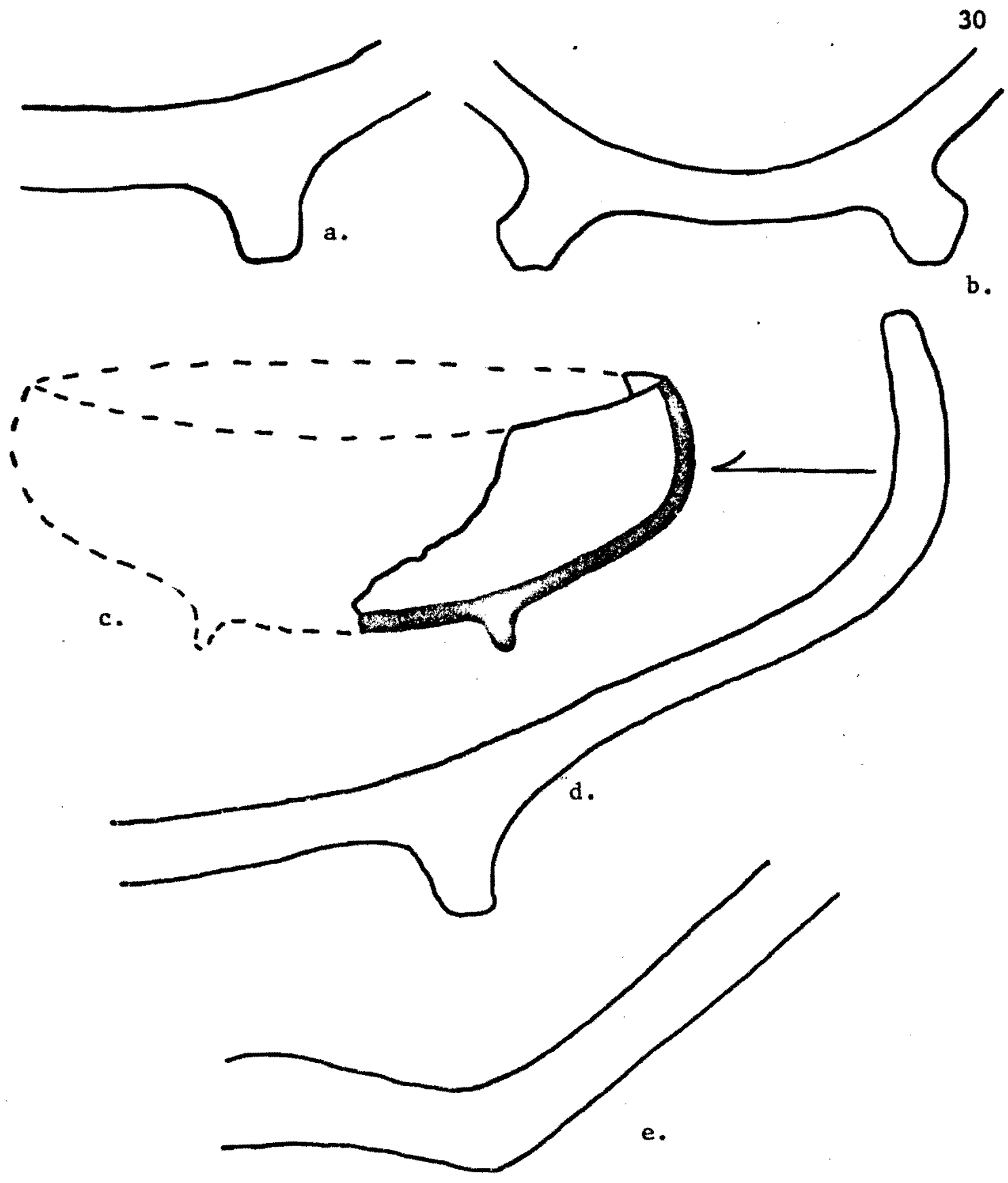

$\longrightarrow 1 \mathrm{CM}$

Figure 9. Base sherd profiles from Site III. Ring-foot bases, a-d; 'dimple' base, e. Interlors drawn to the left. 
III. DISCUSSION OF FORMS

In summary, the three collections can be categorized most meaningfully in terms of their formal characteristics. These can be enumerated according to their distributions in each of the sites.

\section{Site I}

of the 101 sherds from this site, 45 are rim sherds. 30 of these are everted, and 14 are direct. There is one straight rim with a rolled 11p. Nine bases occur in this collection, eight with a foot-ring and one 'dimple' base (Figure 10).

The associations of rims with bases indicate three primary vessel forms: globular bodied pots with everted rims, shallow direct-rimed bowls with foot-rings, and one direct-rimmed vessel with a 'dimple' base.

\section{Site II}

The vessel forms Indicated by the 177 sherds in the collection Include those found at the beach site, as well as some additional Items; vessels with angled shoulders and vessels with tabular handles.

Out of a tutal of $102 \mathrm{rim}$ sherds, 71 are everted, 25 are direct, and six are straight rims with or without a rolled lip. There are 31 base sherds, 28 show a foot-ring, and three are 'dimpled' (Figure 11). These attributes in association indicate the presence of vessels with globular bodies and everted or straight rims, shallow direct-rimmed bowls with foot-rings, an angled 
shouldered vessel with a tabular handle and direct rim, and one vessel with two perforated tabular handles.

\section{S1te III}

45 earthenware sherds were collected from this site. Of the $19 \mathrm{rim}$ sherds, 15 are everted and four are inturned direct rims. A total of 13 base sherds includes nine with foot-rings, three 'dimple' bases, and one flat, circular base which resembles a solid foot-ring (Figure 12).

The vessel forms which have been determined from this known habitation site are those with everted rims and globular bodfes, direct-rinmed wares with foot-rings, and a shallow directrimmed vessel with a 'dimple' base. 


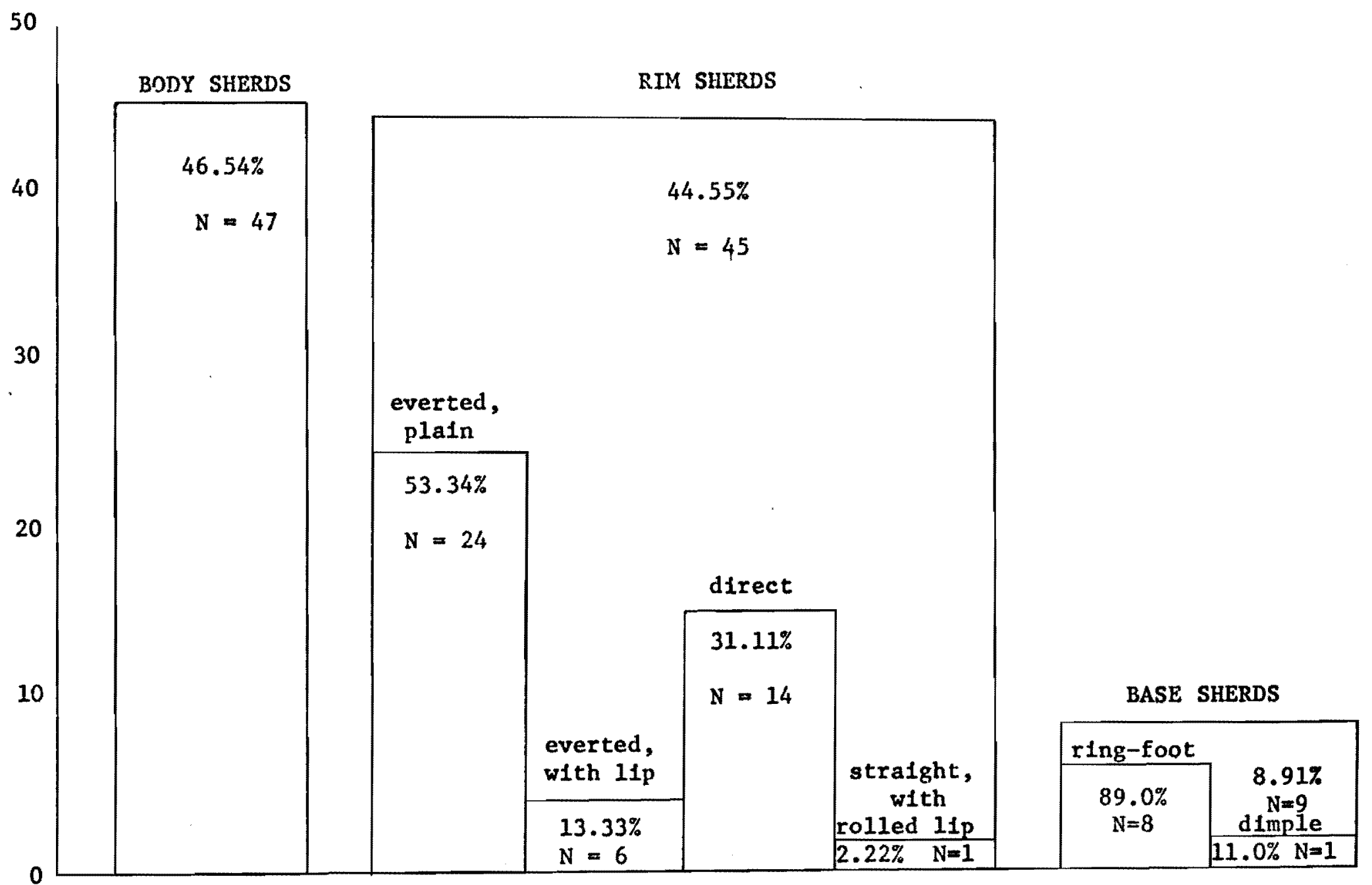

Figure 10. Formal distribution of body, rim and base sherds from S1te I, by percent and number. 


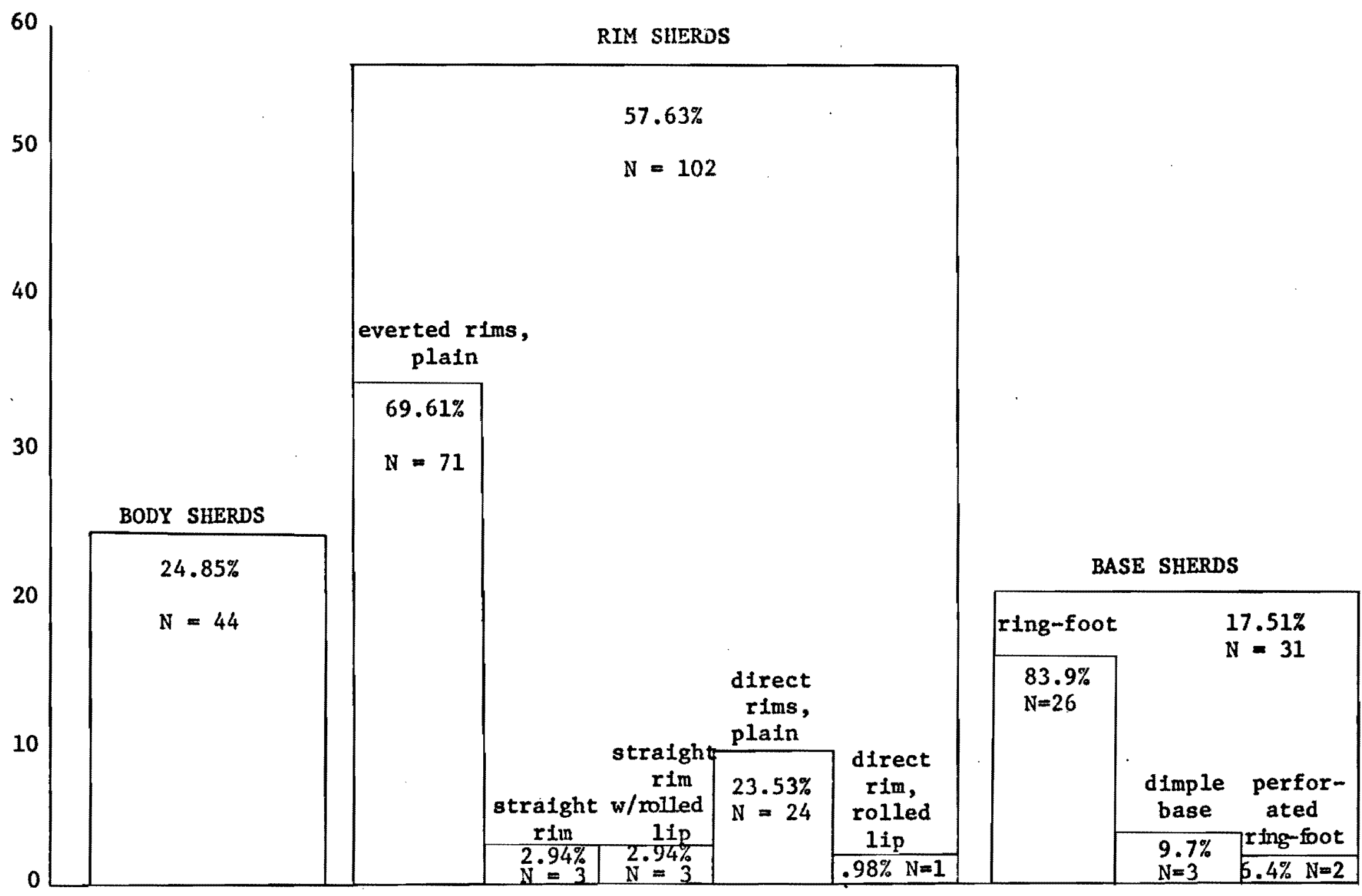

Figure 11. Formal distribution of body, rim, and base sherds from Site II, by percent and number. 


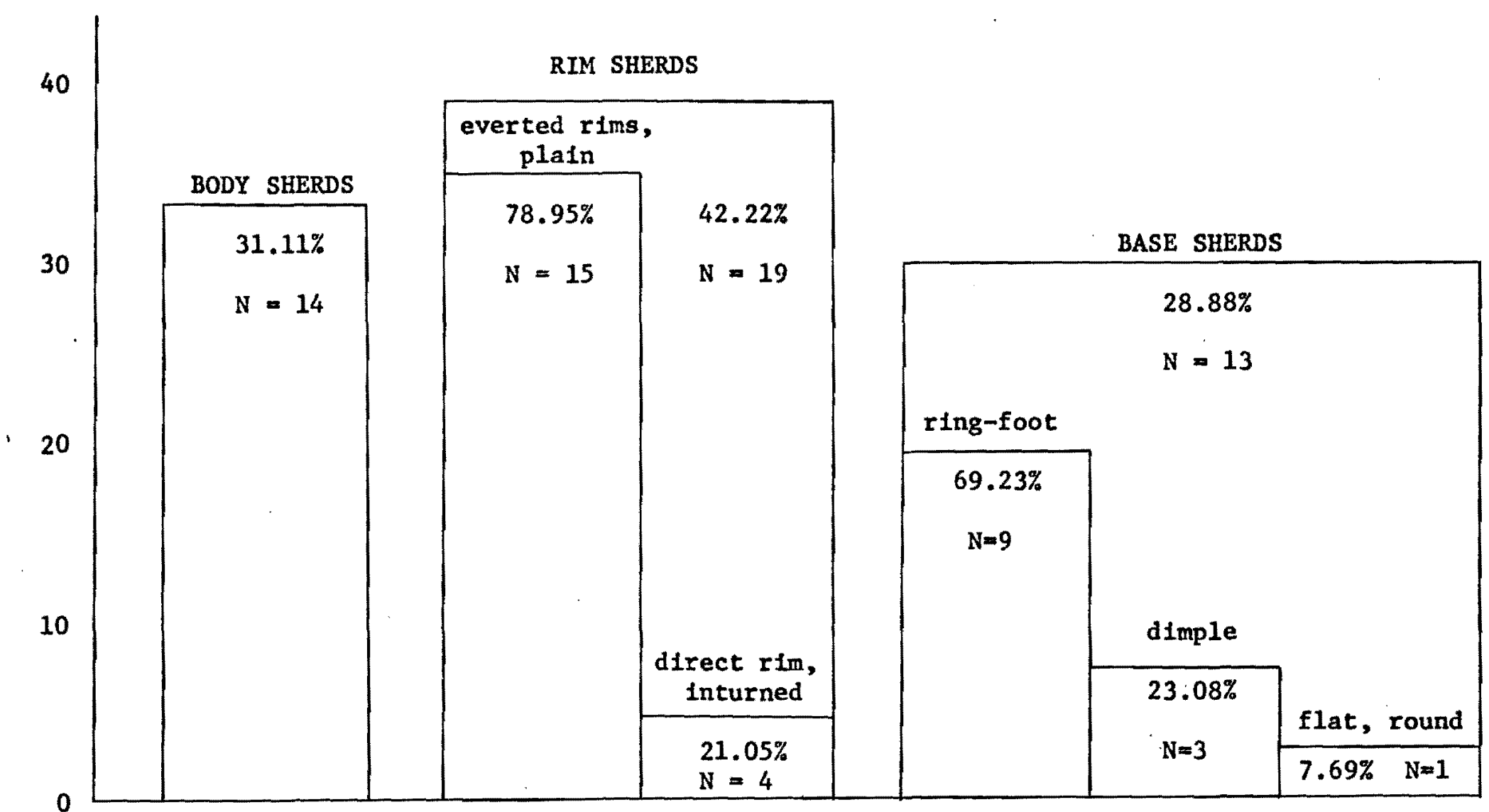

Figure 12. Formal distribution of body, rim and base sherds from Site III, by percent and number. 
CHAPTER IV

\section{CONTEMPORARY UYOGAN EARTHENWARES}

\section{THE LOCAL INDUSTRY}

The pottery industry of Uyogan is geared to meet local needs (Scheans, 1971a). Traditionally, seven different items have been made by the local female potters. These Items include the vanga, a globular bodied root and/or rice pot with an everted rim; the tayab, a meat or vegetable pot, known locally as a "viand" pot, similar to the vanga but with a wider mouth; the angang, a thickwalled water pot with an everted rim; the dalikan, an oblong, floored stove; the horno, a basin-type oven with a direct rim and tabular handles, and totohong, which are vessel covers (Figure 13). These earthenwares are al1 st111 being made at the present time. However, within the last ten years, a number of new items, such as flower pots and toy sets, have been added to the types of wares produced by the potters. These recent Innovations have not been used In our comparison with the archaeological potteries, since it is apparent that their time of manufacture probably antedates the sites involved.

The clay used by the Uyogan potters comes from two locations, both about one kilometer from the town. One of these locales produces a coarse clay used for maklng flower pots and ovens, while the 


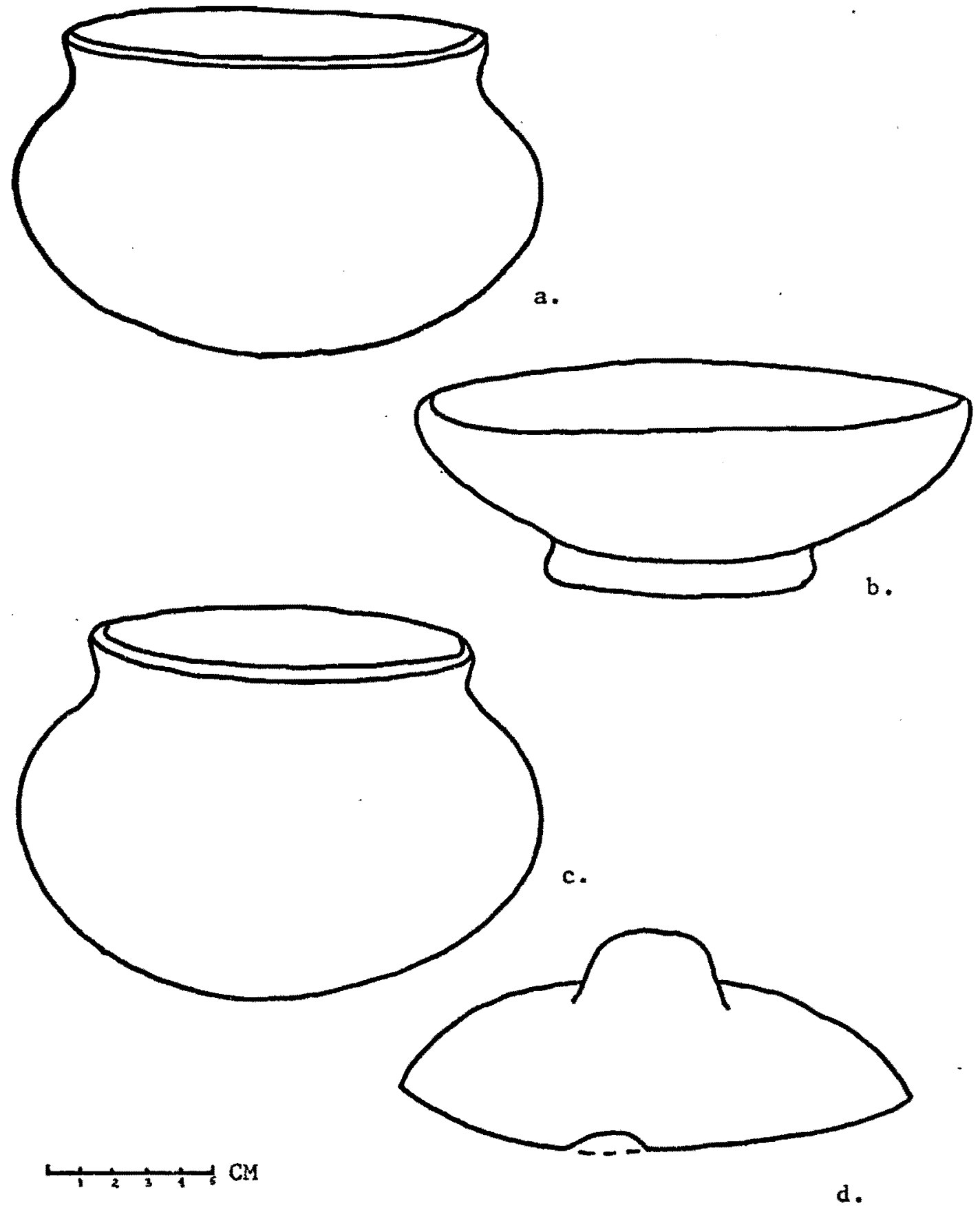

Figure 13. Contemporary Uyogan earthenwares. "Viand" pot (tayab), a; serving/eating bow! (vavanga), b; root/rice pot (vanga), c; vessel cover (totohong), d. 
other clay, finer and more reddish in color, is used for all other 1tems. In preparation, the clay is ground, sieved, and mixed with water. No temper is added.

Briefly, two techniques are used in the bullding of traditional earthenware vessels, modeling and molding, both of which involve the use of rolled out slabs of clay. The vessels are shaped from these slabs with a wooden paddle and a stone anvil. After drying, a red clay slip is applied with a rag. Most vessels are then polished with a cowry shell polishing tool. The wares are then dried and open fired in a pile of wood and grass.

The traditional Uyogan earthenwares are strictly utilitarian items, used in three basic activities, all of which have to do with the handling of foodstuffs. These are: (1) cooking, (2) displaying and serving, or eating, and (3) storage. The vessels which can be included in the cooking category are the root and "viand" pots with everted rims, the stoves and ovens, and the vessel covers. The wares with everted rims are made in a number of sizes, all determined with reference to the amounts winich can be cooked in them, and their mouth diameters, rim heights, and body wall thicknesses vary accordingly. Volume sizes are based upon a standard rice measure, the chupa ( 3.751 1ter). These range from the one-half chupa pot to the eight chupa pot, which are of a sufficient size to cook enough rice for from one to ten persons, respectively. The serving and eating vessels are shallow bowls which have direct rims and foot-rings, and are made in several sizes to accommodate varying amounts of food. 
For storage, the heavier vessels with everted rims and greater body wall thickness are used.

\section{EXTERNAL COMPARISONS}

Earthenwares produced In other areas of the Philippines bear some striking formal resemblances to the cooking and kitchen wares manufactured In Uyogan, although the bullding processes Involved In the production of these items are highly variable interculturally (Scheans, 1966). For comparative purposes, the most significant widespread earthenware item is a globular bodied vessel with an everted rim, similar to the Ivatan vanga. It should be noted, however, that the available ethnographic information generally does not deal extensively with the uses of Filipino earthenwares. A few ethnographic sources have dealt with this subject. Most of these data are from Northern Luzon. Best described are the potteries of the Kalinga, the Bontok, the Tinguian, and the Ilokano, although some information is avallable from the Central and Southern Philippines.

The Kalinga

Kalinga earthenwares have been described, at least in part, by Solheim (1954) and Scott (1958). Scott (1958: 327) included the cooking of rice, meat or vegetables, and the carrying and storage of water as the most conmon uses for earthenware items. Solheim (1954: 2,3) distinguished the vartous forms of the vessels associated with these activities. For cooking, the Kalinga use two types of 
vessels; one with a wide mouth diameter (tayyag) for preparing meat and vegetables, and the other with a narrower opening used only to cook rlce (banga). The Kalinga use large jars, some up to three feet In helght and two feet in diameter, for the storage of water. These vessels have everted rims, angled shoulders, and foot-rings, with the surfaces all slipped and polished.

The Bontok and Bagobo

Less complete information is avallable for the Bontok of Northern Luzon. Jenks (1905: 121) described the Bontok earthenwares in general as "cooking vessels." The illustrations accompanying his text show that these wares are Identical in form to the vanga from Uyogan. A simflar brief observation was made by Cole (1913: 121) concerning the wares produced by the Bagobo of Mindanao.

\section{The TInguian}

Earthenware vessels simflar to the vanga are produced by the Tinguian potters. In discussing the uses of these items, Cole (1922: 428) has stated briefly that ". . porous jars are preferred as water containers, since the seepage lowers the temperature of the contents." Cole (1912: 15) provided a more complete description of cooking as a primary Tinguian earthenware use:

Most tribes of the interfor have pottery of their own manufacture. These generally bear distinctive names according to the uses to which they are put. Thus among the Tingulan a jar used for greens or vegetables has a definite name, while another in which meat is cooked has 1ts own designation. 
The Ilokano

Scheans (1960: 3) has described the potting sequence of the Ilokano banga, a vessel similar to the Ivatan vanga, which is used for cooking. According to Cole (1945: 180), the banga is also used for the storage of liquids.

Central Philippines

The earthenwares of Batan have been compared with those produced on the 1sland of Masbate (Solheim, 1952). Solheim (1952: 51) described the potterles from Masbate as having a single form, but made in three sizes. A small vessel (anglet) is used to cook porridge or fish, a medium-sized one (korron) is for cooking rice and $f$ ish, and a large vessel (banga) is used as a water $j a r$. These wares all have globular bodles with everted rims, and are of the same form as the vanga (Solhelm, 1952: 53). No comparlsons have been made between these three items and the size variation noted in the Ivatan vanga and tayab.

The evidence Indicates that the vanga-like form is widespread among the wares produced by Filipino potters. Similarly, the uses made of this type of 1tem are the same in those areas for which such Information is available. By comparing these recent wares, wth the archaeological potteries found in the Philippines, our inferences concerning earthenware uses in the past are strengthened even more. 


\section{ARCHAEOLOGICAL COMPARISONS}

The scant avallable data which deal with archaeological potteries in the Philippines appear to indicate a certain amount of continuity in the Identiflable traditions. The problem of studying the relationships between the archaeological pottery traditions which have been postulated and the potting methods of the ethnographic present has been discussed by Scheans (1966: 214). However, a number of similarities between these wares can be described.

The Kalanay Complex

Solhelm (1964: 197) has organized the published descriptive Information into three major ceramic complexes for the Southern Philippines. These are the Sa-huynh-Kalanay, the Bau and the Novaliches, all of which he assigns to an approximate time range of from 200 B.C. to 1500 A.D., although Fox (1970: 94) disputes the earlier of these dates.

The majority of the Kalanay materials are from the Visayas, the Calamianes, and Palawan (Solheim, 1964: Figure 6). The Kalanay wares are commonly plain and smooth with a polished red slip (Solhelm, 1959: 180). The two basic forms of these potteries include large, cylindrical jars with flattened bases, and shallow bowls which usually have an attached foot-ring. It is interesting to note that these foot-rings are commonly perforated in a manner which is similar to the perforations on the bases of the Site II collection. (Solhein, 1959: 181). Scheans (1966: 216) has suggested that the 
turned potteries of the Kalanay tradition are part of a continuum extending to the ethnographic potteries of the Ilokano sequence, and that a similar relationship exists between the unturned Bau-Malay potterles and the Bontok and Bagobo sequences.

The Kay Tomas Wares

The Kay Tomas potteries, named after the Calatagan type site of Kay Tomas, have been assigned to the $14 \mathrm{th}$ and 15 th centuries, and constitute an apparently widespread pottery complex in the Batangas area (Fox, 1959: 374). Three distinct types of earthenwares have been found: plain red ware, incised and impressed, and coarse.

Thirteen forms have been noted in the Kay Tomas plain wares, although 90 per cent of these are Included in two globular bodied vessel forms with short everted rims (Fox, 1959: 376). One of these forms has a plain, rounded base, with a mouth dlameter only slightly smaller than the maximum body width. The other form has a smaller mouth opening, and is always associated with a 'dimple' base:

Additional 1tems from Calatagan include flat "plates" with direct rims and foot-rings (Fox, 1959: 378). These foot-rings also occur on smaller vessels resembling "cups." Illustrations of these earthenwares indicate that they are similar to the direct-rimed bowls found in both the recent wares and the archaeologlcal potteries from Batan. 


\section{CHAPTER V}

\section{INTERPRETATION}

The ethnographic information which has been presented corresponds to a statement made by Solheim (1965: 257), that "cooking is probably the major use for locally made earthenware pottery in Southeast Asia today." Assuming that the actual preparation of foodstuffs can be done over a fire without using an oven or stove, the necessary items associated with cooking activities in the Philippines would number no more than five. These include: (1) two types of cooking pots; (2) a water/storage jar; (3) a serving/eating dish; and (4) vessel covers. All of these items have direct analogs in the Ivatan vanga, tayab, angang, vavanga and totohong. It is significant that, with the exception of the potters whose main interests lie in the manufacture of recently introduced items, the wares most commonly produced in Uyogan are the root or rice pots and the water jars.

The potteries found in the known habitation site (Site III) are good evidence that cooking was the primary activity involving earthenwares in the past as we11. Even though the sample is sma11 compared to the other sites, the most numerous sherds are those from vessels with everted rims, and the next most frequently occuring form is the shallow direct-rimmed bowl with a foot-ring. Both of these 
forms resemble almost exactly the modern potteries. Similarly, the collections of wares from Sites I and II are not appreciably different from the materials found at Site III. All three of the collections are directly comparable to the modern wares both in form and size range (Table I), and we can infer that the potterles from each of the surface sites ae characteristic of the types of earthenwares used in the activities associated with food preparation. The repetitious nature of the data merely serves to point out the definite similarity between all of the collections.

If the necessary vessel forms for the handling of food are those found in Uyogan: the root/rice pot, the "viand" pot, and the footringed bowl, then the three collections appear to contain sherds which are representative of these 1tems. Given the correctness of this inferential interpretation, it is now possible for us to identify some ceramic attributes which should be useful in the determination of site functions on Batan. Most useful, we feel, are (1) surface treatment and (2) vessel form.

\section{SURFACE TREATMENT}

The potteries which have been Identified as functionally significant in habitation activities are plain red wares treated with a thick slip prior to firing. These itens most likely will have been polished on one or both surfaces with a smooth polishing tool. The polishing and the application of the slip render the ware less porous, and more serviceable if it is to be used for cooking purposes. The 
TABLE I

SIZE RANGE COMPARISONS OF ARCHAEOLOGICAL AND CONTEMPORARY WARES

\begin{tabular}{|c|c|c|c|c|}
\hline \multirow[t]{2}{*}{ Vessel Portion } & \multicolumn{4}{|c|}{ Mean Size in Centimeters } \\
\hline & Site I & Site II & Site III & Contemporary \\
\hline Body wall thickness & 0.9 & 1.0 & 0.8 & 0.8 \\
\hline Direct rim diameter & 21.8 & 20.1 & 19.8 & 18.8 \\
\hline Everted rim diameter & 18.3 & 17.5 & 17.4 & 16.4 \\
\hline Straight rim diameter & 10.0 & 11.4 & --- & --- \\
\hline Direct rim body diameter & $-m$ & --- & $-m$ & 15.9 \\
\hline Everted rim body dianeter & $-\cdots$ & $-\cdots$ & $--\infty$ & 16.5 \\
\hline Direct rim vessel height & 7.4 & --- & 7.1 & 6.7 \\
\hline Everted rim vessel height & --- & --- & --- & 12.0 \\
\hline Foot-ring diameter & 11.5 & 9.2 & 8.1 & 9.8 \\
\hline
\end{tabular}


possibility of slipping also serving as a method of decoration cannot be determined. The presence of thick, unslipped wares may be an indication of their possible use as water storage containers, since slipping, as indicated, does reduce porosity.

\section{VESSEL FORM}

Those ceramic attributes in the three collections which are assoclated with vessel form, and which are analogous with similar attributes observed in the recent earthenwares include rim and base forms, and the presence of tabular handles.

\section{Kitchen Wares}

Everted rims and globular bodies indicate the presence of vessels used in cooking or storage, while direct rims are associated with serving activities in the form of shallow bowls with foot-rings. The appearance of tabular handles on direct-rimmed wares may indicate that these are from ovens of the horno-type, or possibly from vessel covers. However, the occurence of this form may also be a possible Indication of some cultural contact between the Batanes and other Filipino regions to the south. In the Cebuano-speaking areas, a comnonly produced earthenware iten is the takso or tatsho, a basintype frying pan with two tabular handles below a direct rim (Scheans, 1971b: 31). In any case, both the horno and the takso are used in cooking activities. No positively identifiable stove sherds were found in any of the collections. A few unusually thick body sherds 
may have been parts of stoves, but none of these sherds are diagnostic enough to indicate that this is the case.

\section{Earthenware Disks}

The broken earthenware disk in the collection from site II Is untque, although similar stoneware disks were also found at that site. This is the only earthenware sherd in any of the collections which cannot be considered as evidence of food preparation or handling. Solhein (1965: 259) has discussed the use of such disks:

In the Philippines, and probably elsewhere, potsherds are used as markers in various types of games or in a game vaguely like quolts or bowling, where sherds are tossed to cone as close as possible to a mark or previously thrown sherd, or to knock a sherd out of a ring. The sherds so used are often worked and are sometimes very nicely polished into disks.

There is no reason for us to interpret the presence of this disk as anything other than simply an additional use for earthenware sherds, having as much of a function in habitation activities as any other items.

\section{Miscellaneous}

Included in this category are those attributes or items noted in the archaeological potteries which have no common correlates anong the ethnographically known Batanes wares. These are the straight rims, angled shoulders, and 'dimple' bases.

Straight rims, with elongated necks and of ten with rolled self-lips, may have been produced as items to be used for serving 
or storing liquids. Their restricted mouth diameters would lessen the likelihood of spilling the contents, and might also inhibit IIquid evaporation.

Angled shoulders on otherwise globular vessels are not generally characteristic of the Uyogan earthenwares, although one contemporary "mini-pot" of one-half chupa size has been noted among the recent items. This form is common among the Kalinga potteries (Solheim, 1954: 2), and has also been observed in the Cebuano earthenwares of Albur, Bohol and of Davao (Scheans, 1971b: 7, 30). A comparison of the Cebuano frying pan, takso, and an angled shoulder sherd from Site II (Figure 6; e) has shown that these two items are identical in rim and shoulder form. The presence of only a few sherds of this kind may simply be a further Indication of some form of contact with Northern Luzon and the Central and Southern Philippines.

Two possible interpretations can be offered concerning the occurrence of the 'dimple' base in all of the collections. Since this form is also noted in the Kay Tomas wares, it may indicate contact between the Batanes and Luzon. However, the 'dimpling' effect may also be a flattening technique used on the base of a rounded vessel, in which case, the 'dimple' would appear to serve essentially the sane purpose as the more common foot-ring, i.e., to increase vessel stability. 


\section{CHAPTER VI}

\section{SUMAARY AND CONCLUSIONS}

The characteristic ceramic attributes found in each of the three sites are similar to those known ethnographically to be associated with the preparation and serving of food. Therefore, we can postulate that the sites in which the items having these characteristics were found were in some way connected with such activities. By analogy, these sites can all be inferred to be habitation sites, since the use of a number of forms of cooking vessels indicates that food preparation was the primary activity Involving the use of earthenwares, and that this activity is ethnographically known to occur only at habitation sites. Further, it is possible that the differences which can be observed between the three collections are attributable to diachronic rather than synchronic variation, since the activities at each of the sites were those which relate to habitation.

Three necessary conditions had to be met in order that this study be valid. First, the archaeological potteries had to be systeratically demonstrated to be directly comparable to the modern wares. Second, an historical continuity had to be established between the archaeological sites and the modern town of Uyogan. Third, valid inferences of specific site activities could only be made with complete 
available ethnographlc data for the area. These conditions have all been met by the materials from Batan.

This type of study can yleld information of varying value, and only if the necessary conditions for relevance can be met. For comparative purposes, this method can be useful in obtaining a considerable amount of information on manufacture, use, or site activities from 1solated artifact collections, such as those found In museums. If it is used with care, and with full knowledge of 1ts Ifmitations, this method can provide a means for more thorough analysis of available archaeological materlals. As a procedure for the Incorporation of ethnographic and archaeological data, the method which has been used in this research can be extended to shed light on old problens of description and classification, and may perhaps lead to new questions which can be answered by the often existing but untreated evidence. 
Anderson, Keith H.

1969 "Ethnographic Analogy and Archaeological

Interpretation." Science, 163 (3863): 133-138.

Ascher, Rubert

1961 "Analogy in Archaeological Interpretation."

Southwestern Journal of Anthropology, 17: 317-325.

Baerris, David

1961 "The Ethnohistoric Approach and Archaeology." Ethnolistory, 22: 49-77.

Bemmelen, Reinhard $W$. van

1949 The Geology of Indonesla, Vol. Ia. Government Printing office. The Hague.

Beyer, H. Otley

1947 "Outline Review of Philippines Archaeology by Islands and Provinces." Philippines Journal of Science, 77: 205-374.

Binford, Lewis R.

1967 "Smudge Pits and Hide Smoking: The Use of Analogy

in Archaeological Reasoning." American Antiquity,

32: $1-12$.

1968 "Archaeological Perspectives." IN New Perspectives In Archaeology, Sally R. Binford and Lewis R. Blnford, eds., 5-32. Aldine. Chicago.

Chang, Kwang-chih

1967 "Major Aspects of the Interrelationship of

Archaeology and Ethnology." Current Anthropology,

8: $227-243$.

Cole, Fay-Cooper

1912 "Chinese Pottery in the Philippines." Field

Museum of Natural History Anthropological Series,

12: 3-47. 
Cole, Fay-Cooper

1913 "Wild Tribes of Davao District." Field Museum of Natural History Anthropological Serfes, 12: 49-203.

1922 "The Tinguian." Field Museum of Natural History, 14: 231-493.

1945 The Peoples of Malaysta. D. Van Nostrand Co. Princeton.

Fox, Robert $B$.

1959 "The Calatagan Excavations: Two Fifteenth Century Burial Sites in Batangas, Philippines." Philippine Studies, 7: 325-390.

1970 The Tabon Caves. Monograph of the National Museviti, No. 1. Manila.

Hi11, James $\mathrm{N}$.

1966 "A Prehistoric Community in Eastern Arizona." Southwestern Journal of Anthropology, 22: 9-30.

Honey, William Bowyer

1954. The Ceramic Art of China. Beechhurst Press. New York.

Jenks, Albert E.

1905 "The Bontoc Igorot." Department of Interior, Ethnographic Survey Publications, Vol. 1. Manila.

Keesing, Fellx M.

1962 The Ethnohistory of Northern Luzon. Stanford Untversity Press. Palo Alto.

Linton, Ralph

1936 The Study of Han. Appleton-Century. New York.

Longacre, William A.

1968 "Some Aspects of Prehistoric Society in East-Centra1 Arizona." In New Perspectives in Archaeology, Sally R. Binford and Lewis R. Binford, eds., 89-102. Aldine. Chicago.

Manue1, E. Arsenio

1953 "Informe Sobre Las Islas Batanes (1775-1780)." Philippine Social Sciences and Humanities Review, 18: $99-124$. 
Scheans, Daniel J.

1960 "The Pottery Industry of San Nicholas, Ilocos Norte." Journal of East Aslatic Studies, 9: 1-38.

1966 "A New View of Philippines Pottery Manufacture." Southwestern Journal of Anthropology, 22: 206-219.

1971a "The Contemporary Earthenware Industry of Uyogan." Unpublished manuscript.

1971b "Contemporary Market Potteries of the Cebuano Speaking Areas of the Philippines." Unpublished manuscript.

Scott, W1111am llenry

1958 "Economic and Yaterial Culture of the Kallnga of Madukayan." Southwestern Journal of Anthrogology, 14: 318-337.

Shepard, Anna 0.

1956 Ceramics for the Archaeologist. Carnegie Institution Publication No. 609. Washington, D. C.

Solhelm, Filheln G., II

1952 "Pottery Manufacturing in the Islands of Masbate and Batan, Philippines." Journal of East Aslatic Studies, 1: 49-53.

1954 "Ibanag Pottery Manufacture in Isabela, Philippines." Journal of East Asiatic Studies, 3: 305-307.

1959 "Sa-huynh Related Pottery in Southeast Asla." Astan Perspectives, 3: 177-188.

1960 "Jar-Burlal in the Babuyan and Batanes Islands and in Central Philippines, and Its Relationship to Jar-Burial Elsewhere in the Far East." Philippine Journal of Science, 89: 115-148.

1964 The Archaeology of Central Philippines. National Institute of Science and Technology. Manila.

1965 "The Functions of Pottery in South East Asia: From the Present to the Past." IN Ceramics and Man, F. R. Matson, ed., Viking Fund Publications in Anthropology, 21: $254-274$. 
Tenazas, Rosa C. P.

1968 "A Report on Excavations in Two Sites in the

Barrio of Pinagbayanan, Municipality of Pila, Laguna." Archaeological Report: Locsin-University of San Carlos Excavations.

Thompson, Raymond H.

1956 "The Subjective Element in Archaeological

Inference." Southwestern Journal of Anthropology, 12: $327-332$.

Watson, Patty Jo, Steven LeBlanc and Charles Redman

1971 Explanation in Archaeology. Columbia University

Press. New York.

Wernstedt, Frederick L. and J. E. Spencer

1967 The PhIlippine Island World. University of

Calffornia Press. Berkeley. 


\section{APPENDIX}

\section{STONEWARES, PORCELAIN AND GLASS}

Imported and domestic stoneware, Chinese porcelain, and Filipino-made glass sherds were found along with the earthenwares at Sites II and III. Identifications of these items were made by Professor Scheans and by Mr. Karl Hutterer of the University of Hawail. The imported wares are all of Chinese manufacture, and can be assigned to the Ch'ing dynasty (1644-1912). A few Filipino stoneware sherds were also present in the collection from Site III. It is possible that these were produced in Vigan, Ilocos Sur, and were subsequently brought to the Batanes.

\section{Site II}

A total of elght stoneware sherds were found at this site.

Paste: These are light or dark gray or buff, and are roughened by the presence of non-plastic inclusions.

Firing: The firing temperatures were sufficient to bring the pastes of these sherds to a highly vitrified state.

Hardness Range: 5 to 7 on Moh's scale.

Method of Manufacture: These stonewares are wheel-made, leaving interior ridges or wreathing marks. The exterior surfaces are carefully smoothed.

Surface: Wiping marks are apparent on the surfaces of all of the sherds. 
Color: All of the sherds are glazed, with colors ranging from olive or reddish brown to gray or buff. The thin glazes show tiny holes left by burst bubbles, and the thick glazes form welts at the edges of their application.

Form: All of these stonewares are body sherds, with a body wall thickness range of 0.5 to $0.9 \mathrm{~cm}$.; mean: $0.7 \mathrm{~cm}$.

Disks (Figure 14; a, b): Two stoneware sherds were worked into discoldal shape, with diameters of $4.8 \mathrm{x}$ $5.5 \mathrm{~cm}$, and $4.0 \times 4.0 \mathrm{~cm}$.

\section{Site III}

Eighteen stonewares were collected at this site, representing greater formal variation than those found at Site II.

Paste: These are basically the same as those described for the stonewares at Site II.

Surface: Thick or thin glazes are applied to either the exterior or interior surfaces. Some of these glazes are quite rcugh and mottled, or filled with tiny bubble-holes. A few bare spots can be seen on these sherds, where the glaze has "crawled" during firing. Drip lines in the glazes are common.

Color: The glaze colors are variable, including dark gray, smooth or mottled shades of brown, mottled blue, and buff or cream with brown inclusions. A few of the sherds are only partially glazed, showing a two-tone effect on the exterior surfaces.

Intertors: Wiping marks are deep on the generally unglazed interior surfaces.

Form; Rim and 11p: Four everted Iin sherds occur, all with rolled, rounded or "stepped"lips (Figure $14 ; \mathrm{e}, \mathrm{f}, \mathrm{g}$ ). One of the everted rim sherds has two broken tabular handles at the shoulder, separated by a Chinese ideograph which has been stamped on the shoulder. This symbol may be a potters' shop mark. A single tabular handle occurs in this collection, also attached at the shoulder of an everted rim sherd. The mouth diameters of these sherds range from 10.4 to $14.0 \mathrm{~cm}$; mean: $11.9 \mathrm{~cm}$. 
Body: 12 body sherds occur, one of which has an angled shoulder. Another of these has a wide handle attached horizontally at the shoulder. The body wall thicknesses of these sherds range from 0.5 to $1.0 \mathrm{~cm}$; mean: $0.7 \mathrm{~cm}$.

Base: A single base form is represented by two sherds, both of which are flat and circular, with a basal diameter of 13.5 and $13.0 \mathrm{~cm}$.

\section{Domestic Stoneware}

Five sherds of domestic stoneware, known as "Burnay," were found at site III.

Paste: These wares are heavy, with rough surfaces and more numerous non-plastic inclusions than the Chinese wares.

Color: The pastes of these sherds are all a dark reddish brown.

Hardness Range: 6 to 7 on Moh's scale.

Method of Manufacture: Interfor Indentations and the lack of wreathing marks appear to indicate the use of a paddle and anvil during some part of the building process.

Surface: The interior and exterior surfaces are all thickly slipped with deep wiping marks. The slips are roughened by the presence of numerous tiny holes.

Color: S1ip colors are generally reddish brown, similar to the pastes.

Form; Rim and Lip: Two everted rim sherds occur, with self-rims undercut at the lip (Figure $14 ; \mathrm{c}, \mathrm{d}$ ). The mouth diameters of these rims are 16.0 and $15.0 \mathrm{~cm}$.

Body: Three body sherds are present, having a mean body wall thickness of $0.8 \mathrm{~cm}$. 
Porcelain

Four porcelain sherds are present in the collection of Imported wares from Site III. These Include two body sherds, one sherd with a direct rim, and one foot-ringed base. One of the body sherds has a light green crazed exterfor glaze and an unglazed buff interior. The other has an off-white exterior glaze and a blue-on-white patterned interfor (Figure 14; h). Both of these wares have a body wall thickness of $0.4 \mathrm{~cm}$.

The direct-rimed sherd is of a porcelain bisque with a grayish-white glaze. It appears to have been part of a small bowl, with a body wall thIckness of $0.3 \mathrm{~cm}$. , and a mouth diameter of $12.5 \mathrm{~cm}$.

The foot-ringed base is of gray enamelled porcelain with a crazed exterior surface. This sherd resembles those wares known as "Swatow," after the southern Chinese port from which they are presumed to have been exported (Honey, 1954: 127). This sherd has a body wall thickness of $0.3 \mathrm{~cm}$. , and the foot-ring diameter $1811.5 \mathrm{~cm}$.

\section{Glass}

Two sherds of glass were found at the known habitation site. One is an Iridescent blue-green, semi-opaque piece, and the other Is a body sherd from a San Miguel Brewery beer bottle. Both of these 1tems are probably of F1lipino manufacture, and they appear to be Intrusive items which were dropped at the site. 

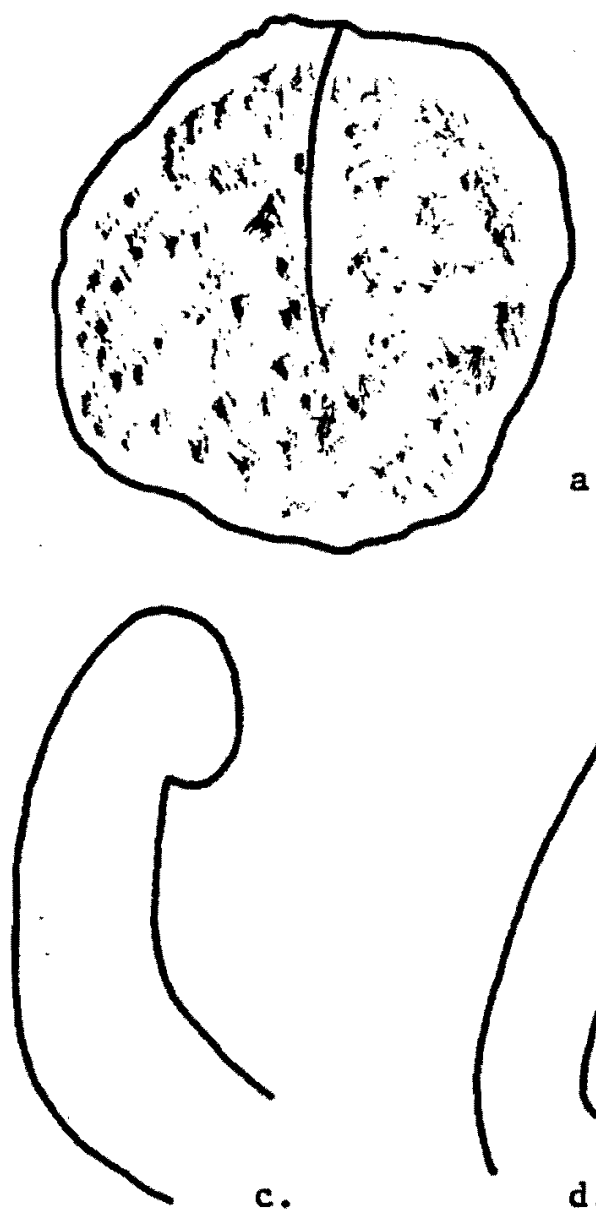

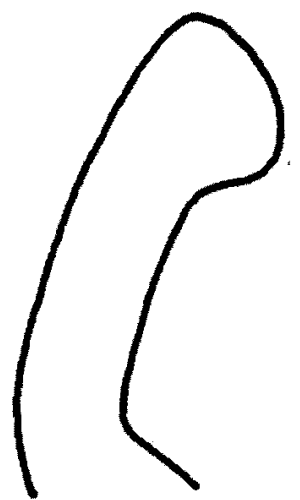

d.

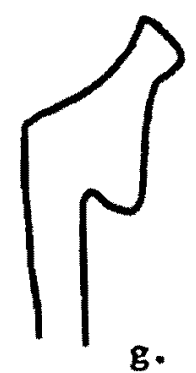

g.
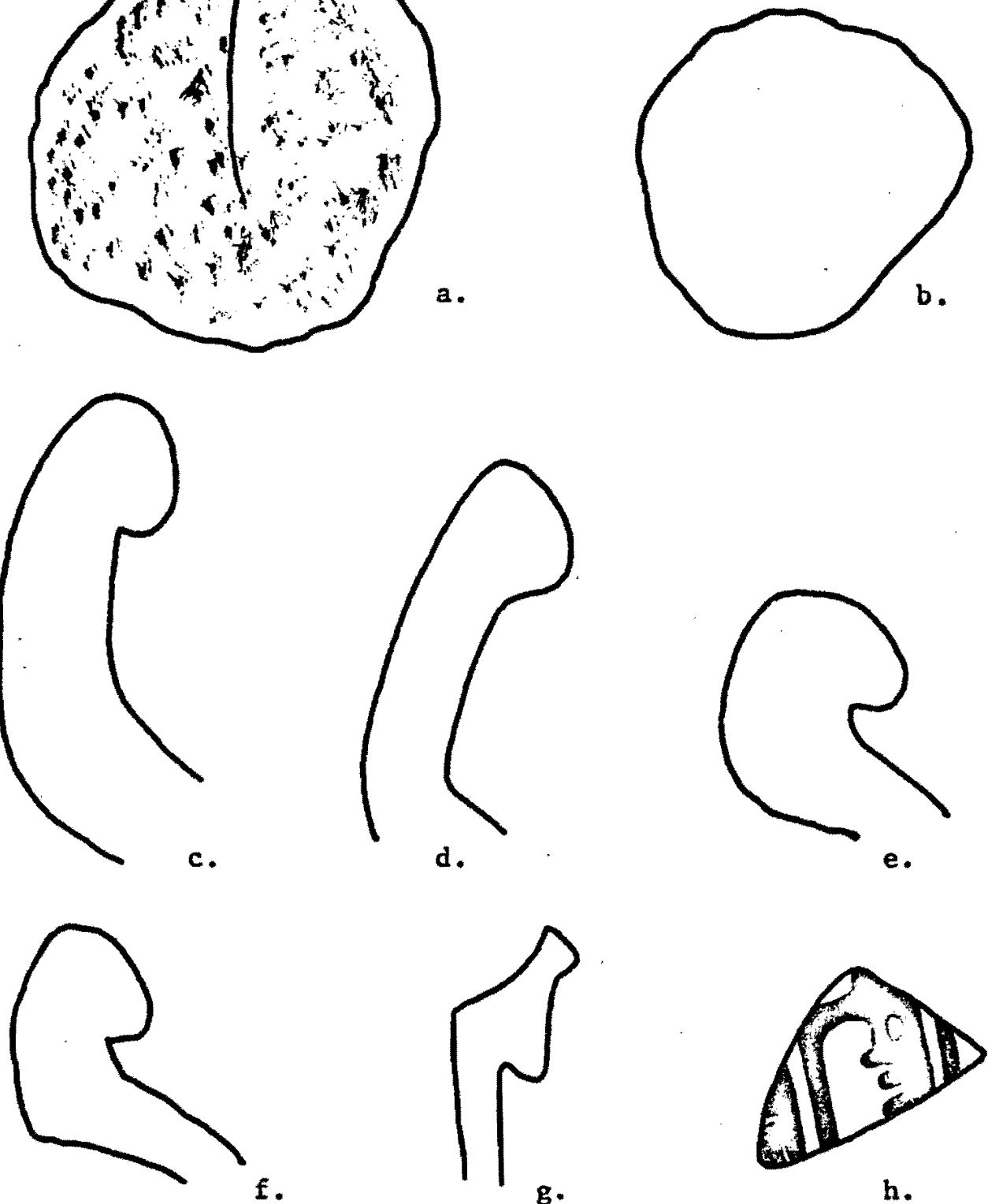

h.

$\longrightarrow \mathrm{CM}$

Figure 14. Domestic and imported stoneware and porcelain sherds. Chinese stoneware disks, $a$ and b; rim proftles of domestic sherds, $c$ and d; rim profiles of Chinese stoneware, e - $g$; blue-on-white Chinese porcelain, $h$. Interiors of rims drawn to the left. 